\title{
Hydration of Portland cement with additions of calcium sulfoaluminates
}

\author{
Gwenn Le Saoût ${ }^{\text {a,* }}$, Barbara Lothenbach ${ }^{\text {a }}$, Akihiro Hori ${ }^{\text {b }}$, Takayuki Higuchi ${ }^{c}$, Frank Winnefeld ${ }^{\text {a }}$ \\ a Empa, Swiss Federal Laboratories for Materials Science and Technology, Concrete and Construction Chemistry Laboratory, Überlandstrasse 129, CH-8600 Dübendorf, Switzerland \\ b DENKA Chemicals GmbH, Wehrhahn-Center, Cantadorstr. 3, D-40211 Düsseldorf, Germany \\ c Denki Kagaku Kogyo Kabushiki Kaisha (DENKA), Omi, Itoigawa, Niigata, 949-0393, Japan
}

\begin{abstract}
A B S T R A C T
The effect of mineral additions based on calcium aluminates on the hydration mechanism of ordinary Portland cement (OPC) was investigated using isothermal calorimetry, thermal analysis, X-ray diffraction, scanning electron microscopy, solid state nuclear magnetic resonance and pore solution analysis. Results show that the addition of a calcium sulfoaluminate cement (CSA) to the OPC does not affect the hydration mechanism of alite but controls the aluminate dissolution. In the second blend investigated, a rapid setting cement, the amorphous calcium aluminate reacts very fast to ettringite. The release of aluminum ions strongly retards the hydration of alite but the $\mathrm{C}-\mathrm{S}-\mathrm{H}$ has a similar composition as in OPC with no additional $\mathrm{Al}$ to $\mathrm{Si}$ substitution. As in CSA-OPC, the aluminate hydration is controlled by the availability of sulfates. The coupling of thermodynamic modeling with the kinetic equations predicts the amount of hydrates and pore solution compositions as a function of time and validates the model in these systems.
\end{abstract}

Keywords:

Blended cement (D)

Calorimetry (A)

Thermodynamic calculations (B)

Pore solution (B)

Calcium sulfoaluminates (D)

\section{Introduction}

Ordinary Portland cement (OPC) with mineral additions based on $\mathrm{CaO}, \mathrm{SO}_{3}$ and $\mathrm{Al}_{2} \mathrm{O}_{3}$ are used in increasing amounts in both concrete practice and special applications [1]. They are used as rapid setting cement with high early strength [2] or as shrinkage reducer [3]. Many of the rapid hardening and expansive cements increase the formation of ettringite [4] for fast setting and development of strength [5]. In OPC, ettringite begins to form almost immediately after water is added to cement [6]. The mineral additions based on $\mathrm{CaO}, \mathrm{SO}_{3}$ and $\mathrm{Al}_{2} \mathrm{O}_{3}$ increase the amount of ettringite and the kinetics of the processes is of utmost importance. In expansive cements, a large percentage of the ettringite must form after some degrees of strength have developed in order to obtain an expansion effect. In the case of rapid setting cement, ettringite should form in a large amount immediately after mixing, before significant strength has developed.

Two types of mineral additions are used in this study. The rapid setting component is an amorphous calcium aluminate (ACA) with a composition close to $\mathrm{C}_{12} \mathrm{~A}_{7}$ blended with anhydrite. $\mathrm{C}_{12} \mathrm{~A}_{7}$ hydrates rapidly $[7,8]$ and is used as the main ingredient in quick-setting agents for shotcrete and hardening accelerators for concrete $[9,10]$. The expansive cement is a calcium sulfoaluminate cement (CSA)

\footnotetext{
* Corresponding author at: École des Mines d'Alès, Centre des Matériaux de Grande Diffusion (CMGD), 6, avenue de Clavières, 30319 Alès Cedex, France. Tel.: + 3346678 5312; fax: + 33466785355 .

E-mail address: gwenn.le-saout@mines-ales.fr (G. Le Saoût).
}

based on ye'elimite, free lime and anhydrite and represents an important expansive additive in Japan [3].

This study focuses on the influence of these additives on the OPC hydration kinetics. A thermodynamic model [11] is used to predict the composition of the liquid and the solid phase as function of hydration time of these two types of cements and compared with the experimental data.

\section{Experimental details}

\subsection{Materials}

The chemical and mineralogical compositions of the raw materials are given in Table 1 . The unhydrated cement is an ordinary Portland cement (OPC) CEM I 42.5N. The two additives are a calcium sulfoaluminate cement (labeled CSA) and an amorphous calcium aluminate based accelerator mixed with anhydrite (labeled ACA). The composition of the amorphous calcium aluminate has been determined based on Rietveld analysis and XRF data of ACA and checked by SEM-EDX. It is mainly composed by $\mathrm{CaO}$ and $\mathrm{Al}_{2} \mathrm{O}_{3}$ with small amount of $\mathrm{SiO}_{2}$. The $\mathrm{Al} / \mathrm{Ca}$ and $\mathrm{Si} / \mathrm{Ca}$ atomic ratios are respectively 1.14 (by SEM-EDX: 1.07 ) and 0.07 (by SEM-EDX: 0.07). The composition is close to $\mathrm{C}_{12} \mathrm{~A}_{7}(\mathrm{Al} / \mathrm{Ca}=1.17)$. The proportions of the raw materials in the three mixes are reported in Table 1.

\subsection{Hydration experiments}

The pastes were formulated to have a water to binder mass ratio of 0.5 and were mixed 3 min with a high shear blender. A retarder 
Table 1

Mineralogical and chemical compositions of the cement OPC, additives CSA, ACA and formulations.

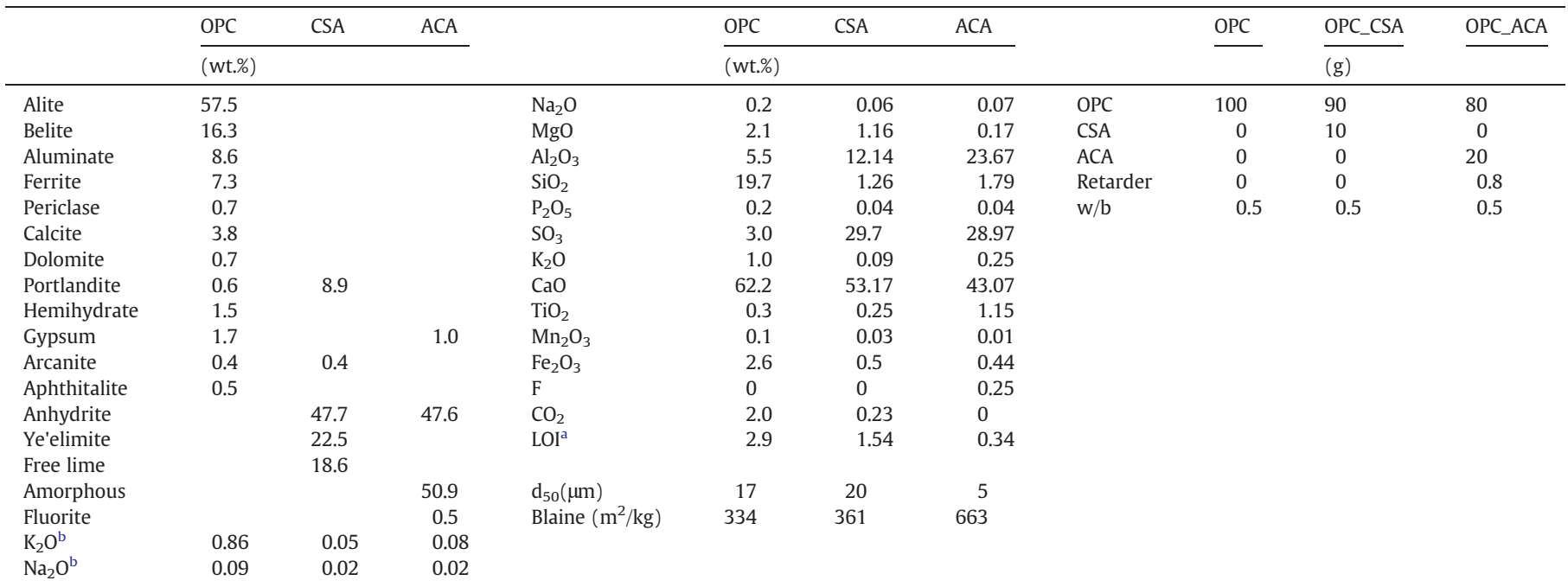

Mineralogical composition determined by XRD/Rietveld analysis. Chemical analysis by XRF, except $\mathrm{SO}_{3}$ measured with a Leco apparatus.

a Loss on ignition (LOI) measured until $950{ }^{\circ} \mathrm{C}$.

b Readily soluble alkalis calculated from the concentrations of alkalis measured in the solution after 5 min of agitation at a water to raw materials of 10 .

was mixed with the OPC blended with ACA in order to control the setting time. A conduction calorimeter (TAM Air from Thermometric $\mathrm{AB}$, Sweden) operating at $20^{\circ} \mathrm{C}$ was used to determine the hydration heat flow using the admix ampules described in [12]. Two grams of solids was weighted into the sealed glass ampule. A shaft for a mixer and a syringe needle for water injection are placed centrally in the lid of the ampule. One gram of liquid was filled into the syringe. The top part of the syringe plungers are placed outside the calorimeter. The arrangement of the syringes permits the sample and the water to be separately thermostated in the calorimeter thermostat before the measurement is started by the injection of the water and mixing (see [12] for details).

\subsubsection{Analysis of the solid phases}

The fresh paste was poured into plastic bottles of $12 \mathrm{~mL}$ until completely filled; the bottles were sealed, and then stored at $20^{\circ} \mathrm{C}$. Prior to the TGA, XRD and NMR analyses, hydration was stopped after $1.5,3,12$, and $18 \mathrm{~h}$ and $1,3,7,28$ and 91 days by submerging small pieces, each around $2-3 \mathrm{~mm}^{3}$, for $30 \mathrm{~min}$ in about $50 \mathrm{~mL}$ isopropanol and rinsing twice with diethylether. Thermogravimetric analyses (TGA, Mettler Toledo) were performed using about $60 \mathrm{mg}$ of powder at a heating rate of $20^{\circ} \mathrm{C} . \mathrm{min}^{-1}$ under nitrogen and from $30{ }^{\circ} \mathrm{C}$ to $980^{\circ} \mathrm{C}$. The amounts of bound water and portlandite respectively were deduced from the weight losses between $40-550{ }^{\circ} \mathrm{C}$ and $450-550{ }^{\circ} \mathrm{C}$.

$\mathrm{X}$-ray diffraction (XRD) data were collected using a PANalytical $X$ 'Pert Pro MPD diffractometer in a $\theta-2 \theta$ configuration using incident beam monochromator employing the $\mathrm{CuK}_{\alpha}$ radiation $(\lambda=1.54 \AA)$ with a fixed divergence slit size $0.5^{\circ}$ and a rotating sample stage. The samples were scanned between $5^{\circ}$ and $70^{\circ}$ with the X'celerator detector. The Rietveld analysis was performed with the X'Pert High Score Plus software (version 2.1). The anhydrous OPC was analyzed using the protocol described in [13]. The structure models used for the Rietveld refinement of the CSA are given in [14]. The amount of amorphous in the anhydrous ACA sample has been calculated by the method of standard addition using corundum as internal standard (see details in [15]). For the hydrated paste, the method of external standard (G-factor approach) has been used to quantify the X-ray amorphous part $[16,17]$. The mass attenuation coefficients of the samples were determined by X-ray fluorescence analysis from data in Table 1 taking into account the amount of bound water determined by TGA. Results of Rietveld analyses gave the sum of the phases normalized to $100 \mathrm{wt} . \%$. Due to the hydration reactions, water is bound in the hydrates so the total amount of solids increases. In order to correct for this dilution effect, the amount of bound water by TGA was deduced, so that the results always refer to the mass of anhydrous materials. We should stress that there can be differences between the Rietveld quantification and the real composition of anhydrous OPC (see [13] and references inside). The extent of these differences for hydrated paste is unclear. The results of the Rietveld quantification in such complex mixtures should be taken with care and considered as a semi quantitative determination.

The ${ }^{29} \mathrm{Si}$ MAS NMR spectra were recorded on a Bruker Avance 400 NMR spectrometer (field strength of 9.4 T, Bruker Biospin AG, Fällanden, Switzerland) at $79.49 \mathrm{MHz}$ applying $4.5 \mathrm{kHz}$ spinning rates on a $7 \mathrm{~mm}$ CP MAS probe using $\mathrm{ZrO}_{2}$ rotors. Single-pulse experiments were carried out by applying $90^{\circ}$ pulses of $8.8 \mu$ s with ${ }^{1} \mathrm{H}$ decoupling of $31.3 \mathrm{kHz}$ (TPPM15) and recycle delays of $20 \mathrm{~s}$ to allow for the relaxation time $\mathrm{T}_{1}$ of the species present in the samples. The ${ }^{29} \mathrm{Si}$ chemical shift was referenced externally relative to tetramethylsilane at $0.0 \mathrm{ppm}$. The observed ${ }^{29} \mathrm{Si}$ resonances were analyzed using the $\mathrm{Q}^{\mathrm{n}}(\mathrm{mAl})$ classification, where one Si tetrahedron is connected to $n$ Si tetrahedral with $n$ varying from 0 to 4 ; and $m$ is the number of neighboring $\mathrm{AlO}_{4}$ tetrahedra. The relative proportions of silicon associated with the $Q^{\mathrm{n}}$ units were determined by the decomposition of the spectra using the Dmfit program [18]. The mean chain length and the $\mathrm{Al} / \mathrm{Si}$ atomic ratio of the $\mathrm{C}-$ S-H were calculated as described by Richardson et al. [19]:

- average alumina-silicate chain length $\mathrm{CL}$ :

$C L=2 \frac{\left(Q^{1}+Q^{2}+\frac{3}{2} Q^{2}(1 A 1)\right)}{Q^{1}}$

- average $\mathrm{Al}(\mathrm{IV}) / \mathrm{Si}$ atomic ratio for the tetrahedral chains:

$\frac{\mathrm{A} 1(\mathrm{IV})}{\mathrm{Si}}=\frac{\frac{1}{2} \mathrm{Q}^{2}(1 \mathrm{~A} 1)}{\left(\mathrm{Q}^{1}+\mathrm{Q}^{2}+\mathrm{Q}^{2}(1 \mathrm{~A} 1)\right)}$. 
The degree of hydration $\mathrm{DOH}$ of the anhydrous silicate phases (alite and belite) is defined as:

$\mathrm{DOH}=\mathrm{Q}^{1}+\mathrm{Q}^{2}+\mathrm{Q}^{2}(1 \mathrm{~A} 1)$.

This DOH can be compared with the XRD-Rietveld analysis using the following equation:

$\mathrm{DOH}=100\left[\frac{\left(\mathrm{SiO}_{2}\right)^{\mathrm{XRF}}-(\text { alite })^{\mathrm{XRD}}\left(\mathrm{SiO}_{2}\right)^{\text {alite }}-(\text { belite })^{\mathrm{XRD}}\left(\mathrm{SiO}_{2}\right)^{\text {belite }}}{\left(\mathrm{SiO}_{2}\right)^{\mathrm{XRF}}}\right](4)$

where:

$\left(\mathrm{SiO}_{2}\right)^{\mathrm{XRF}}$ amount of $\mathrm{SiO}_{2}$ in the anhydrous mix calculated from XRF analysis,

(alite/belite) XRD amount of alite/belite calculated from XRD analysis, $\left(\mathrm{SiO}_{2}\right)^{\text {alite/belite }}$ amount of $\mathrm{SiO}_{2}$ in alite and belite assuming the Taylor composition [4].

The ${ }^{27} \mathrm{Al}$ MAS NMR spectra were obtained at $104.26 \mathrm{MHz}$ on a $2.5 \mathrm{~mm}$ CP MAS probe using the above mentioned NMR system. Single pulse experiments were carried out at $20 \mathrm{kHz}$ spinning rates by applying single pulse $(\pi / 12)$ excitation pulses of $0.5 \mu \mathrm{s}$ and $0.5 \mathrm{~s}$ relaxation delays. The ${ }^{27} \mathrm{Al}$ chemical shifts were referenced relative to a $1.0 \mathrm{~mol} \mathrm{~L}^{-1} \mathrm{AlCl}_{3}-6 \mathrm{H}_{2} \mathrm{O}$ solution at $0.0 \mathrm{ppm}$. The lineshape of the peaks associated with ettringite and AFm were described by a Lorentzian function and the Czjzek model, respectively. The Lorentzian lineshape for the ettringite peak reflects the high symmetrical sixfold coordination of aluminum sites [20] that lead to no or weak quadrupolar effects. AFm on the other hand is poorly crystallized and the quadrupolar interaction leads to asymmetry in the lineshape that can be well described by the Czjzek model with a quadrupolar coupling Cq around 1.3 MHz [21,22].

For the microscopical investigations, slices of hydrated samples were cut, immediately immersed in isopropanol for three days and then subsequently dried at $40{ }^{\circ} \mathrm{C}$ for $24 \mathrm{~h}$. Afterward, they were impregnated using a low viscosity epoxy and polished down to $0.25 \mu \mathrm{m}$ using diamond pastes. The samples were further coated with carbon $(\sim 5 \mathrm{~nm})$ and examined using a Phillips FEG-XL30 scanning electron microscope (SEM) coupled to energy dispersive X-ray spectroscopy (EDX) analyser from EDAX. The EDX point analyses were used to determine the elemental compositions of the hydrate assemblage. The analyses were carried out using an accelerate voltage of $15 \mathrm{kV}$ to ensure a good compromise between spatial resolution and adequate excitation for the $\mathrm{FeK}_{\alpha}$ peak. Over 60 points (EDX spots) per sample were analyzed.

\subsubsection{Analysis of the pore solutions}

For pore solution extraction, samples consisting of $1 \mathrm{~kg}$ binder and $0.5 \mathrm{~kg}$ water were mixed according to the EN-196-3 standard. The pastes were cast in $500 \mathrm{~mL}$ polyethylene (PE) bottles, sealed and stored in a thermostatic bath. Pore solutions during the first hours were collected by vacuum or pressure filtration. After one day, pore fluids were extracted using the steel die method and pressures up to $530 \mathrm{~N} \cdot \mathrm{mm}^{-2}$ [11]. In all cases, the solutions were immediately filtered using $0.45 \mu \mathrm{m}$ nylon filters. $5 \mathrm{~mL}$ aliquots were diluted with $20 \mathrm{~mL}$ Milli-Q water. The total concentrations of the element analyzed were determined using an inductively plasma optical emission spectrometer (ICP-OES), type VistaPro (Varian). The pH was measured using a Knick pH meter equipped with a Knick SE 100 electrode calibrated against $\mathrm{KOH}$ solutions of known concentrations. It is important to note that the large volume of sample used for the pore solution analysis, in comparison with the volume used for other techniques, may lead to different hydration kinetics due to the difference in self-heating.

\subsubsection{Chemical shrinkage}

The chemical shrinkage analyses were performed according to ASTM C 1608-07 [23]. The chemical shrinkage CS in $\mathrm{mL}$ per unit mass of cement at time $t$ is computed as:

$\mathrm{CS}(\mathrm{t})=\frac{\mathrm{h}(\mathrm{t})-\mathrm{h}(\mathrm{x})}{\mathrm{M}_{\text {cement }}}$

where $\mathrm{M}_{\text {cement }}$ is the mass of cement in the vial and $\mathrm{h}(\mathrm{t})$ is the water level in capillary tube at time $\mathrm{t} . \mathrm{h}(\mathrm{x})$ is the water level taken at the reference time $\mathrm{x}=60 \mathrm{~min}$ according to the norm.

\subsubsection{Compressive strengths}

Compressive strength was measured according to Japanese Industrial Standard JIS R 5201. $40 \times 40 \times 160 \mathrm{~mm}$ mortar bars were cast at $20{ }^{\circ} \mathrm{C}$ and $95 \%$ of relative humidity using water binder ratio of 0.5 and binder sand ratio of 3 . The specimens were demoulded the following day, then cured under water at $20{ }^{\circ} \mathrm{C}$ and tested at $1.5,3$, 12 , and $18 \mathrm{~h}$ and $1,3,7$, and 28 days.

\subsection{Thermodynamic modeling}

Thermodynamic modeling was used to calculate the effective saturation index of various hydrate phases which could potentially form in the pastes, using the measured composition of the pore solution and also to model the hydration processes. The Gibbs free energy minimization software GEMS $[24,25]$ was used. The thermodynamic data for aqueous species as well as for many solids were taken from the PSI-GEMS thermodynamic database [26], while the solubility products for cement minerals were taken from the cemdata07 database $[27,28]$. The cemdata07 dataset includes thermodynamic data of common cement minerals such as $\mathrm{C}-\mathrm{S}-\mathrm{H}$, different AFt and AFm phases, hydrotalcite and hydrogarnets. No restrictions on the kind of hydrates calculated were imposed, with the exception of siliceous hydrogarnet $\left(\mathrm{C}_{3} \mathrm{AS}_{0.8} \mathrm{H}_{4.4}\right)$, whose formation was suppressed as its formation seems to be kinetically hindered at ambient temperature.

The saturation index (SI) with respect to a solid is given by $\log \left(\mathrm{IAP} / \mathrm{K}_{\mathrm{s} 0}\right)$, where the ion activity product IAP is calculated from activities derived from the concentrations determined in the solution and $\mathrm{K}_{\mathrm{s} 0}$ signifies the solubility product of the respective solid. A positive saturation index implies over saturation, a negative value under saturation with regard to the respective solid. As the use of saturation indices can be misleading when comparing phases which dissociate into a different number of ions, "effective" saturation indices were calculated by dividing the saturation indices by the number of ions participating in the reactions $(\mathrm{n})$ to form the solids: $1 / \mathrm{n} \log \left(\mathrm{IAP} / \mathrm{K}_{\mathrm{s} 0}\right)$. The formation from the dominant ions $\mathrm{OH}^{-}, \mathrm{Ca}^{2+}, \mathrm{SO}_{4}^{2-}$, or $\mathrm{Al}(\mathrm{OH})^{4-}$ in the solution was considered but not the influence of $\mathrm{H}_{2} \mathrm{O}$; the values for gypsum, portlandite, ettringite or monocarbonate were divided by $2,3,15$ or 11 , respectively. All calculated saturation indices refer to the solubility products of the solids as given in [27-29].

Thermodynamic modeling of the hydration of OPC, OPC_CSA and OPC_ACA systems was carried out in a similar manner as described before for Portland cement [11,28,30,31], calcium sulfoaluminate cement [32], and Portland cement blended with calcium sulfoaluminate cement $[14,33]$. By combining an empirical model or experimental data that describes the dissolution of the clinker phases a function of time with a thermodynamic equilibrium model that assumes equilibrium between the solution and the hydrates, the hydrates formed can be described as a function of time. The composition of the phases as given in Table 1 was used as input to calculate the composition of the solid and the liquid phase as a function of time. 
Due to its variable composition, the $\mathrm{C}-\mathrm{S}-\mathrm{H}$ phase was modeled using a solid solution model with the end-members jennite $(\mathrm{CaO})_{1.67}$ $\left(\mathrm{SiO}_{2}\right)_{1}\left(\mathrm{H}_{2} \mathrm{O}\right)_{2.1}$ and tobermorite $(\mathrm{CaO})_{0.83}\left(\mathrm{SiO}_{2}\right)_{1}\left(\mathrm{H}_{2} \mathrm{O}\right)_{1.3}$. The model was originally developed by Kulik and Kersten $[34,35]$ and later adapted by Lothenbach et al. [28]. The uptake of aluminum by C-S-H was simply taken into account by using the $\mathrm{Al} / \mathrm{Si}$ ratio in the $\mathrm{C}-\mathrm{S}-\mathrm{H}$ measured by ${ }^{29} \mathrm{Si}$ NMR as thermodynamic models allowing the Al-uptake by $\mathrm{C}-\mathrm{S}-\mathrm{H}$ to be calculated are not yet available. According to the ${ }^{29} \mathrm{Si}$ NMR results (see below), the atomic ratio $\mathrm{Al} / \mathrm{Si}$ of the $\mathrm{C}-\mathrm{S}-\mathrm{H}$ has been fixed to 0.08 . To model the uptake of alkali by $\mathrm{C}-\mathrm{S}-\mathrm{H}$, a distribution ratio $\mathrm{R}_{\mathrm{d}}$ of $0.42 \mathrm{~mL} / \mathrm{g}[11,36]$ was used for both $\mathrm{Na}$ and $\mathrm{K}$.

Based on the predicted volume of unhydrated blends and the hydration products, the chemical shrinkage $\left(\mathrm{CS}_{\mathrm{GEMS}}\right)$ and the total porosity ( $\left.\mathrm{P}_{\mathrm{GEMS}}\right)$ can be calculated according to the following equations:

$\mathrm{CS}_{\mathrm{GEMS}}(\mathrm{t})=\mathrm{V}(\mathrm{t}=0)-\mathrm{V}(\mathrm{t})$

$\mathrm{P}_{\mathrm{GEMS}}(\mathrm{t})=100 \frac{\left[\mathrm{V}(\mathrm{t}=0)-\mathrm{V}_{\text {solid }}(\mathrm{t})\right]}{\mathrm{V}(\mathrm{t}=0)}$

where: $\mathrm{V}(\mathrm{t}=0)$ is the initial volume of dry material and water, $\mathrm{V}_{\text {solid }}(\mathrm{t})$ is the volume of hydrates added to the remaining volume of anhydrous at time $t, V(t)$ is $V_{\text {solid }}$ added to the volume of the pore solution at time $t$.

For the porosity calculations, the volume of the sand present was also included to correspond to the mortar experiments, while the calculation for the chemical shrinkage includes no sand as chemical shrinkage has been determined in paste samples.

\section{Results and discussion}

\subsection{Solid phase assemblage}

\subsubsection{Heat of hydration}

In the case of the OPC, the heat release during the initial period $(0$ to $0.5 \mathrm{~h}$, Fig. 1d) is assigned to the dissolution of free lime, reactive sulfates (arcanite, hemihydrate and aphthitalite), partial dissolution of anhydrite and aluminate and the initial precipitation of ettringite following the findings of $[6,37,17]$. The initial period is followed by an induction period (Fig. 1c). This induction period may be related to the nucleation of C-S-H (see [38] and references therein). During the induction period, anhydrite can still dissolve and ettringite slowly precipitates [6]. The acceleration period (4-20 h, Fig. 1b) for the OPC is mainly due to the fast dissolution of alite and the precipitation of portlandite and C-S-H phase [4]. A shoulder in the heat flow after the acceleration period is observed in OPC after $20 \mathrm{~h}$ and is assigned to the renewed hydration of $C_{3} A[6,39]$.

The heat release during the initial period ( 0 to $0.5 \mathrm{~h}$, Fig. $1 \mathrm{~d}$ ) is higher for the OPC_CSA than for the OPC due to the higher amount of sulfates and free lime. As for the OPC, we observe similar induction and acceleration periods. As previously shown by Nocuń-Wczelik et al. [40] for a Portland cement mixed with $10 \mathrm{wt} . \%$ of $\mathrm{CaO}$ and anhydrite, the hydration is not especially disturbed in the presence of CSA (OPC_CSA) compared to the OPC alone during the first $24 \mathrm{~h}$ of hydration. However, the shoulder assigned to the renewed hydration of $\mathrm{C}_{3} \mathrm{~A}$ occurs much later in the OPC_CSA, at around $50 \mathrm{~h}$, compared to the OPC. As noticed by Minard et al. [41], the increase of sulfates ions from anhydrite in the pore solution will bind to $\mathrm{C}_{3} \mathrm{~A}$ and retard the hydration.

The heat release during the initial period ( 0 to $0.5 \mathrm{~h}$, Fig. $1 \mathrm{~d}$ ) is even more intense for OPC_ACA. As stressed by Sakai et al. [2] in a study on a formulation closed to OPC_ACA, the large heat release is probably due to the fast dissolution of the amorphous calcium aluminate and the formation of ettringite. Whereas an induction period is observed both in OPC and OPC_CSA, the OPC_ACA system presents an important heat release composed of two peaks. The main features of the hydration of $\mathrm{C}_{12} \mathrm{~A}_{7}$ in water are similar to those of CA [42].
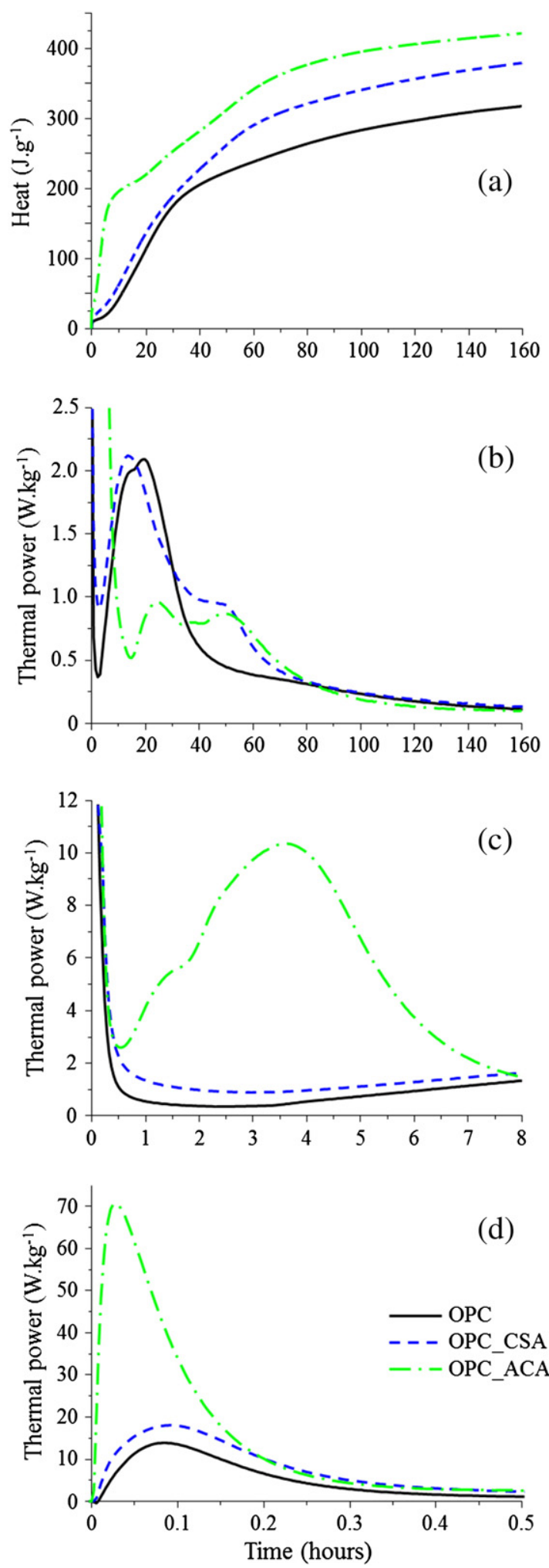

Fig. 1. Cumulative heat of OPC, OPC_CSA and OPC_ACA pastes (a) and heat flow development, as a function of time, between 0-160 h (b), 0 and 8 h (c), and 0-0.5 h (d).

During the initial period anhydrite dissolves rapidly while only a small amount of $\mathrm{C}_{12} \mathrm{~A}_{7}$ reacts. Ettringite and $\mathrm{AH}_{3}$ are formed according to Eq. (8).

$\mathrm{C}_{12} \mathrm{~A}_{7}+12 \mathrm{C} \overline{\mathrm{S}}+137 \mathrm{H}_{2} \mathrm{O} \rightarrow 4 \mathrm{C}_{6} \mathrm{AS}_{3} \mathrm{H}_{32}+3 \mathrm{AH}_{3}$ 
The short induction period is then controlled by the nucleation and growth of $\mathrm{AH}_{3}$ followed by a period of massive precipitation of hydrates (ettringite and/or $\mathrm{SO}_{4}-\mathrm{AFm}$ and $\mathrm{AH}_{3}$ ). During this period the hydration rate is divided in two exothermic peaks but the origin of these two peaks is still unclear. Alternatively, the formation of an amorphous layer around the CA has been suggested to retard the reaction [43]. A delay of $10 \mathrm{~h}$ for the reaction of the Portland clinker (see also the XRD results given below) and a lower heat release are observed. As previously reported [44,45], the release of aluminate ions by reaction of $\mathrm{C}_{12} \mathrm{~A}_{7}$ retards the alite hydration. As in the case of the OPC_CSA, the renewed hydration of $C_{3} A$ is retarded by the presence of sulfate ions.

Fig. 1a displays the cumulative heat of hydration that reflects the previous observations: compared to the OPC and OPC_CSA, a significantly more heat is released in the OPC_ACA during the first hours (heat evolved at $24 \mathrm{~h}$ in J.g ${ }^{-1}: 140,158$ and 233 respectively in the OPC, OPC_CSA and OPC_ACA). After $40 \mathrm{~h}$ and longer, clearly more heat is observed for the OPC_CSA than for the OPC.

\subsubsection{Chemical shrinkage}

OPC and OPC_CSA have similar chemical shrinkage at early age and above $40 \mathrm{~h}$; more hydrated products are formed in the OPC_CSA. The fast reaction of OPC_ACA compared to the OPC is also clearly observed in the high chemical shrinkage at early age. The cumulative heat of hydration is mirrored in the high chemical shrinkage of the pastes (Fig. 2a) as previously reported [46].

\subsubsection{X-ray diffraction and thermogravimetric analysis}

The consumption of the alite during hydration deduced by XRDRietveld analysis is shown in Fig. 3a. We observe similar kinetics of the alite reaction for the OPC and OPC_CSA. The hydration of alite in OPC_ACA is delayed compared to OPC and OPC_CSA which agree with the calorimetric measurements. Even after 91 days, less alite
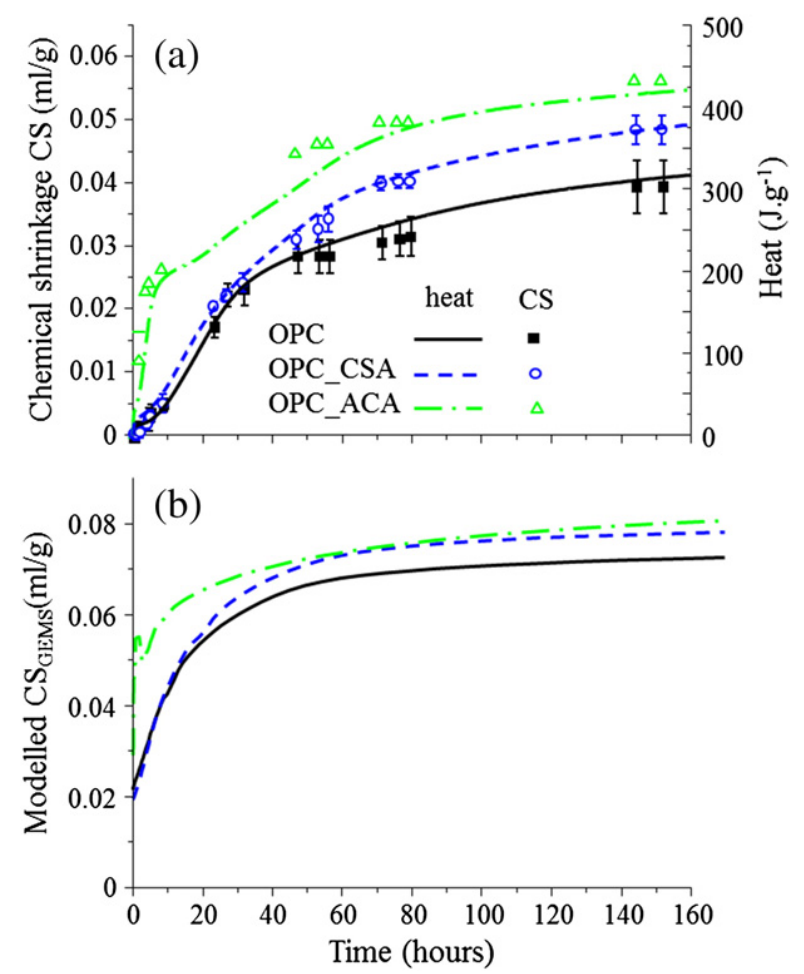

Fig. 2. Calculated chemical shrinkage CS relative to the blended cement content (symbol) compared with cumulative heat (line), as a function of time (a). Modeled chemical shrinkage as a function of time calculated by GEMS (b).
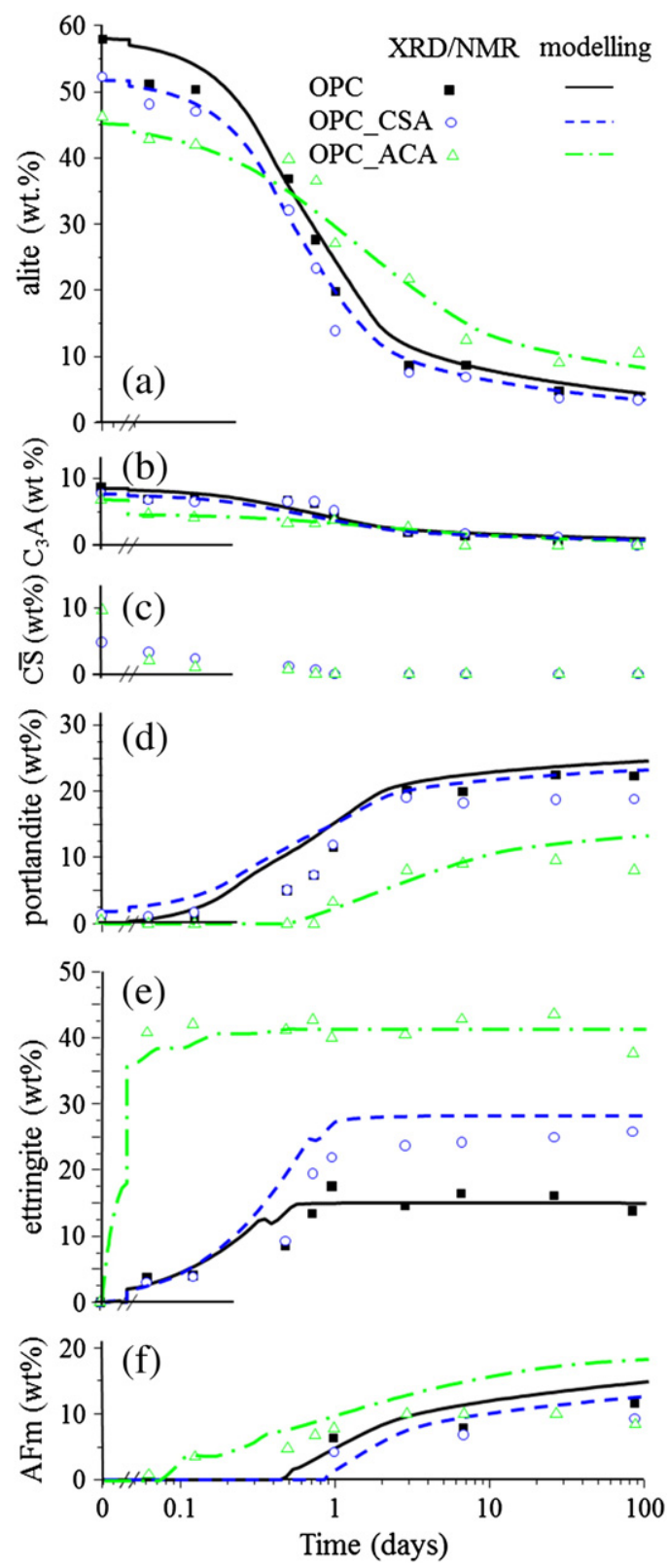

Fig. 3. Amounts of alite (a), $C_{3} A(b)$, anhydrite (c), portlandite (d), ettringite (e) deduced by XRD-Rietveld analysis and AFm (f) deduced by ${ }^{27} \mathrm{Al} \mathrm{NMR}\left(\mathrm{CO}_{3}-\mathrm{AFm}\right.$ is assumed) as a function of time. Lines in ( $\mathrm{a}$ and $\mathrm{b}$ ) are calculating using the cement hydration model of Parrott and Killoh [73], and lines in (b, d, e, and f) refer to the results of thermodynamic modeling.

has reacted in OPC_ACA. Belite reacts much less in all systems than alite (not shown) and presents a degree of hydration of $20 \%$ at 91 days. The lower amount of alite reacted in OPC_ACA is mirrored in the lower amount of portlandite (Fig. 3d). The initial reaction of the $C_{3} A$ is faster for OPC_ACA than for the other two systems as shown in Fig. $3 b$. The fast $C_{3} A$ reaction could be related to the fast consumption of calcium sulfate in this system. The kinetics of reaction of the ferrite phase is similar as $C_{3}$ A but approximately $50 \mathrm{wt}$.\% has reacted at 91 days (not shown).

Gypsum and hemihydrate are consumed in OPC and OPC_CSA systems before $18 \mathrm{~h}$ (see TGA curves in Fig. 5 for gypsum), the anhydrite in OPC_CSA within one day (Fig. 3) and the ye'elimite within 1-3 days. The presence of lime and anhydrite may retard the hydration of ye'elimite $[47,48]$. The presence of anhydrite in OPC_CSA and OPC_ACA 
causes the delay in the $C_{3} A$ hydration (see Fig. 1b), as the high dissolved sulfate concentrations in the presence of unreacted calcium sulfates retard the $\mathrm{C}_{3} \mathrm{~A}$ reaction [41]. In parallel to the reaction of calcium sulfates, ettringite is present within the first hour and the amount increases with time until about one day.

In the OPC_ACA, gypsum is consumed within $1.5 \mathrm{~h}$, as well as the main part of anhydrite ( $8 \mathrm{wt} . \%$ from total $10 \mathrm{wt} . \%$ ), followed by a slow decrease up to one day when all anhydrite is consumed. The amount of ettringite reaches a plateau within $1.5 \mathrm{~h}$ in the OPC_ACA and remains more or less constant afterwards (Figs. 3-5). The fast dissolution of sulfates and precipitation of ettringite correspond to the significant heat release observed during the first minutes (Fig. 1d). In all systems, the formation of AFm phases (hemi and monocarbonate) is observed (Figs. 3-5). As previously observed by XRD during the hydration of OPC containing calcite [30], hemicarbonate is detected first and then transformed slowly to monocarbonate. According to Eq. (8), some $\mathrm{AH}_{3}$ may be formed in OPC_ACA. The main endotherm of $\mathrm{AH}_{3}$ - gibbsite is around $300{ }^{\circ} \mathrm{C}[49]$ where no significant heat loss is observed in the differential TGA curves. We should stress that the $\mathrm{AFm}$ and $\mathrm{AH}_{3}$ phases are usually difficult to follow by XRD. The strätlingite as well as hydrotalcite
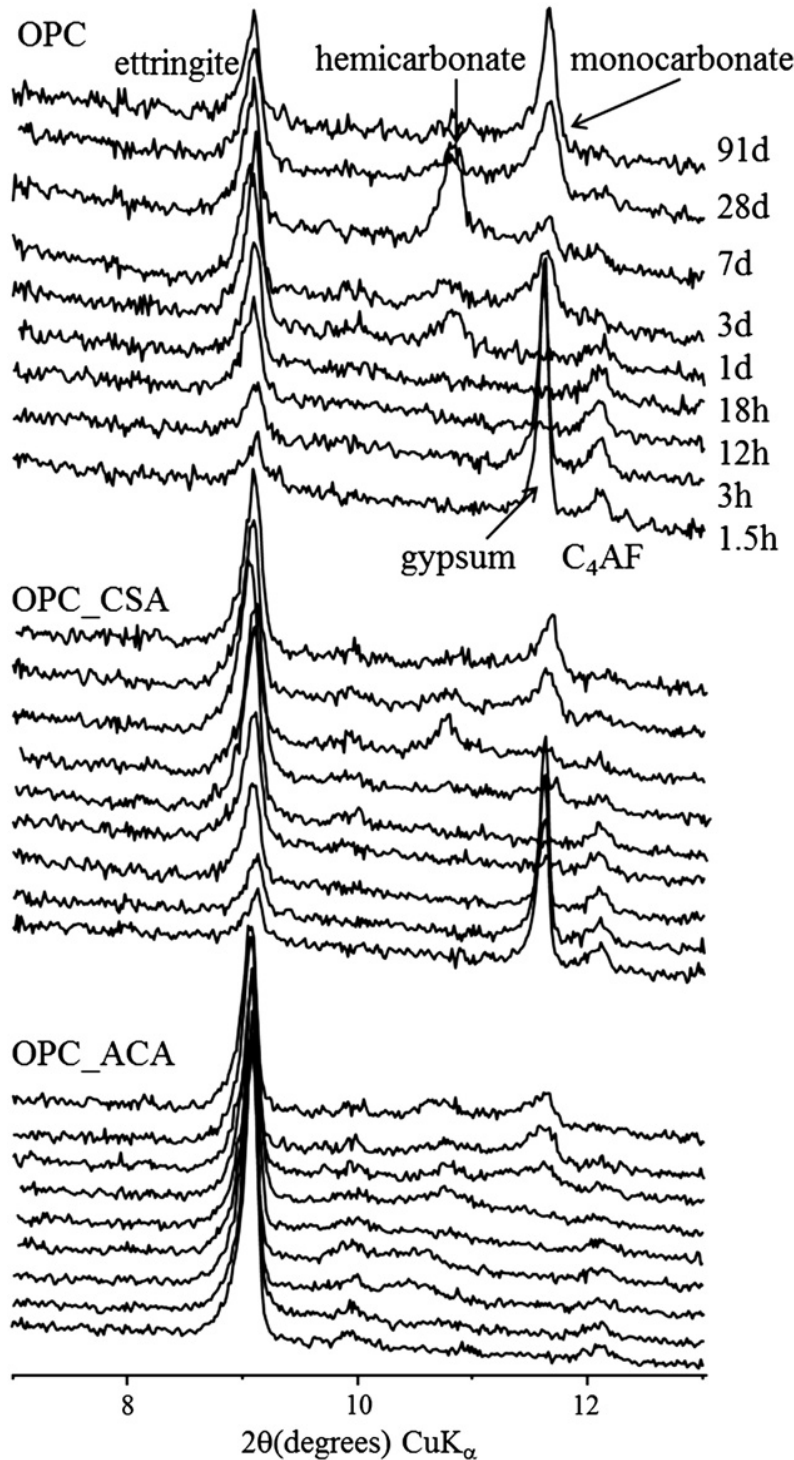

Fig. 4. Observed diffraction patterns between 7 and $13^{\circ} 2 \theta$ degrees $\left(\mathrm{CuK}_{\alpha}\right)$ for hydrated OPC, OPC CSA and OPC ACA pastes.
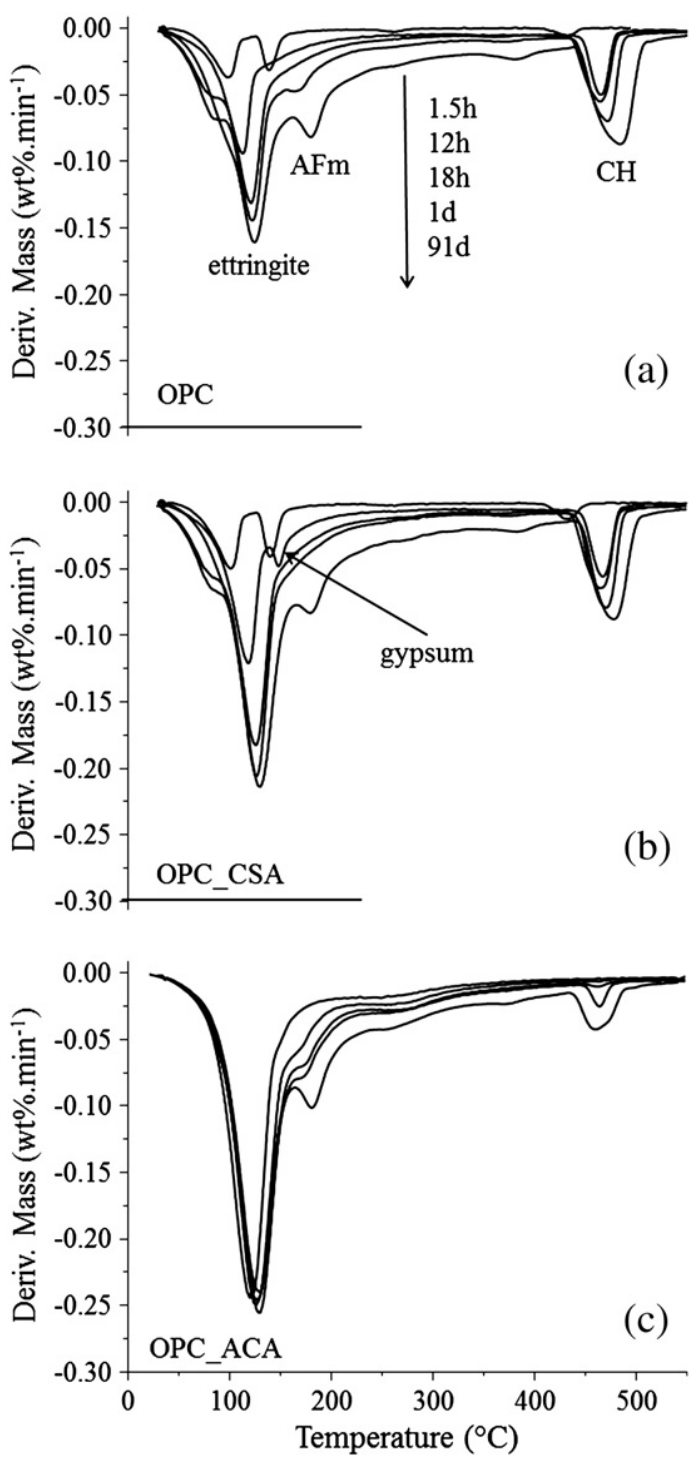

Fig. 5. Differential TGA data for hydrated OPC (a), OPC_CSA (b) and OPC_ACA (c) pastes.

and monocarbonate phases belong to the layered double hydroxides (LDHs) that often present rather broad XRD peaks. Various kinds of disorder may appear during the crystallization process leading to a loss of "crystallinity" (see [50,51]).

\subsubsection{Backscattered electron images (SEM-BSE)}

The backscattered electron image of the polished surfaces of the OPC hydrated for 28 days (Fig. 6a) show the typical features expected in a Portland cement $[74,52]$. The hydration products $(\mathrm{CH}, \mathrm{C}-\mathrm{S}-\mathrm{H}$, $\mathrm{AFm}$, and AFt phases) are observed as rims around the clinker grains and/or fill the porosity. The observations are similar for the OPC_CSA. However, at 28 days (Fig. 6b), much more hollow shell hydration grains (also called Hadley grains) are present. The reason for this phenomenon is unclear but the aluminate phase and the amount of sulfate seem to play a major role [52].

A plot of $\mathrm{Al} / \mathrm{Ca}$ ratios against $\mathrm{Si} / \mathrm{Ca}$ ratios from the EDX analysis indicate for both OPC and OPC_CSA the presence of portlandite and $\mathrm{C}-\mathrm{S}-\mathrm{H}(\mathrm{Ca} / \mathrm{Si}=1.7)$ which corresponds to the mean $\mathrm{Ca} / \mathrm{Si}$ atomic ratio previously reported in OPC [52]. The $\mathrm{Al} / \mathrm{Si}$ atomic ratio in the $\mathrm{C}-\mathrm{S}-\mathrm{H}$ is around 0.12 (Table 2 ) in all systems at 28 days. The 

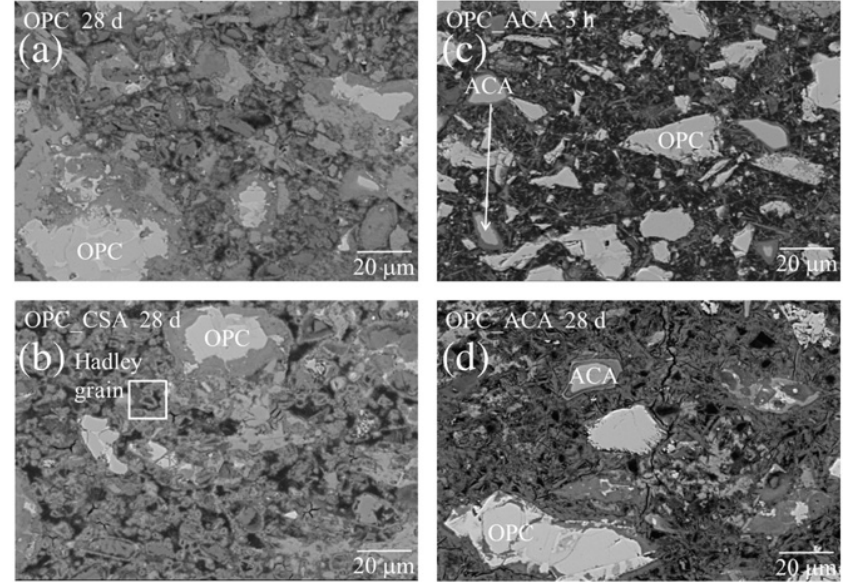

Fig. 6. Backscattered electron images of hydrated OPC (a), OPC_CSA (b) and OPC_ACA

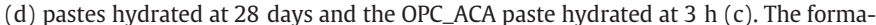
tion of separated hydration shells (Hadley grains) is clearly visible in OPC_CSA (b). At $3 \mathrm{~h}$, in the OPC_ACA (c), ACA reacts (small particle already fully reacted) and ettringite needles can be seen.

OPC_CSA system shows much more points between those of $\mathrm{C}-\mathrm{S}-\mathrm{H}$ and ettringite indicating a higher amount of ettringite than in the OPC.

The OPC_ACA behaves clearly different. At 3 h (Fig. 6c) needle-like ettringite crystals grows outwards from the surface and a hydrated shell appears around the $C_{12} A_{7}$ grains. The smaller grains of $C_{12} A_{7}$ are nearly fully hydrated. SEM-EDX analyses of the hydrated shell reveal that the composition is close to strätlingite $\left(\mathrm{C}_{2} \mathrm{ASH}_{8}\right)$ as shown in Fig. 7b. Rinaldi et al. [53] showed that the formula for strätlingite with ideal composition is $\left[\mathrm{Ca}_{2} \mathrm{Al}(\mathrm{OH})_{6}\right]^{+}\left[(\mathrm{T}, \square)_{4}(\mathrm{OH}, 0)_{8}\right]^{-} 2.25 \mathrm{H}_{2} \mathrm{O}$ where $\square$ represents a vacant tetrahedral site and $\mathrm{T}$ can be either $\mathrm{Si}$ or Al. This implies a variability of the $\mathrm{Al}$ to $\mathrm{Si}$ atomic ratio although no study reports the variability range. As the amount of $\mathrm{SiO}_{2}$ in the $\mathrm{C}_{12} \mathrm{~A}_{7}$ is relatively small, we may assume that the silica originates from the small amount of alite dissolved at the beginning of the hydration. We can also note the absence of sulfate in the hydrated shell (not shown). The strätlingite appears to grow preferentially on hydrated aluminate calcium particles and ettringite outward from the particle surface, similar to observations in a high-alumina cement-zeolite system [54]. However, the assignment to strätlingite has to be confirmed as neither XRD nor NMR (see below) shows evidence of strätlingite.

At 28 days (Fig. 6d), more anhydrous OPC grains are still present in OPC_ACA than in the other systems confirming the lower hydration degree of the OPC observed by XRD. The plot of $\mathrm{Al} / \mathrm{Ca}$ ratios against $\mathrm{Si} / \mathrm{Ca}$ ratios (Fig. 7a), for OPC_ACA at 28 days, indicates a large amount of AFm-AFt and a low amount of portlandite in the matrix. We do not

Table 2

Average tetrahedral chain length $\mathrm{CL}, \mathrm{Al} / \mathrm{Si}$ atomic ratio and degree of hydration derived from ${ }^{29} \mathrm{Si}$ NMR analysis compared with the DOH deduced from XRD-Rietveld data for samples hydrated 91 days. $\mathrm{Ca} / \mathrm{Si}$ and $\mathrm{Al} / \mathrm{Si}$ atomic ratios for $\mathrm{C}-\mathrm{S}-\mathrm{H}$ obtained using SEM-EDX analysis for samples hydrated 28 days. *Errors are estimated assuming the following error bars: $\left(\mathrm{SiO}_{2}\right)_{\mathrm{XRF}}: 0.4 ;\left(\mathrm{SiO}_{2}\right)_{\text {alite }}: 1.2 ;\left(\mathrm{SiO}_{2}\right)_{\text {belite }}: 2$, (alite $)_{\mathrm{XRD}}: 1$ and (belite) XRD $_{2.5}$.

\begin{tabular}{lllllll}
\hline Samples & $\begin{array}{l}\mathrm{CL} \\
(\mathrm{NMR})\end{array}$ & $\begin{array}{l}\mathrm{Al} / \mathrm{Si} \\
(\mathrm{NMR})\end{array}$ & $\begin{array}{l}\mathrm{Al} / \mathrm{Si} \\
(\mathrm{SEM}-\mathrm{EDX})\end{array}$ & $\begin{array}{l}\mathrm{Ca} / \mathrm{Si} \\
(\mathrm{SEM}-\mathrm{EDX})\end{array}$ & $\begin{array}{l}\mathrm{DOH} \\
(\text { NMR })\end{array}$ & $\begin{array}{l}\mathrm{DOH}^{*} \\
(\mathrm{XRD})\end{array}$ \\
\hline OPC & $3.9(0.1)$ & $0.08(0.01)$ & $0.11(0.03)$ & $1.7(0.2)$ & $75(2)$ & $77(6)$ \\
OPC_CSA & $3.8(0.1)$ & $0.07(0.01)$ & $0.12(0.05)$ & $1.9(0.4)$ & $78(2)$ & $75(6)$ \\
OPC_ACA & $3.8(0.1)$ & $0.08(0.01)$ & $0.12(0.04)$ & $2.0(0.2)$ & $61(2)$ & $60(8)$ \\
\hline
\end{tabular}

(a)
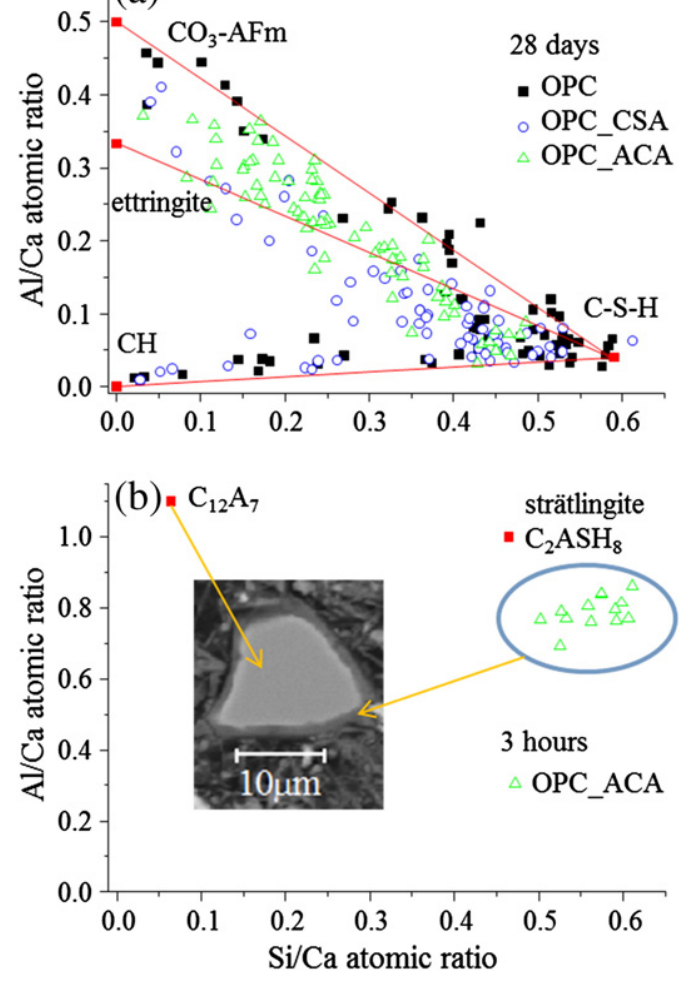

Fig. 7. $\mathrm{Al} / \mathrm{Ca}$ atomic ratio plotted against $\mathrm{Si} / \mathrm{Ca}$ atomic ratio for individual $\mathrm{X}$-ray microanalyses of the matrix of cement pastes at 28 days (a) and the hydrated shell in the OPC_ACA after $3 \mathrm{~h}$ (b). Red points represent pure phases and red lines, a mix between two pure phases.

observe clear difference in the $\mathrm{Si} / \mathrm{Ca}$ ratio of the $\mathrm{C}-\mathrm{S}-\mathrm{H}$ deduced by SEM-EDX (Table 2) as all values are within error bars. Furthermore, as $\mathrm{C}-\mathrm{S}-\mathrm{H}$, portlandite, ettringite and AFm, are strongly intermixed in a micron level in this system, the $\mathrm{Ca} / \mathrm{Si}$ atomic ratio may be difficult to determine using SEM-EDX analysis [55].

\subsubsection{Solid state NMR}

The fast reaction of the amorphous calcium aluminate phase in the OPC_ACA samples may lead to significant Al to Si substitution in the C-S-H. However, the ${ }^{29}$ Si NMR spectra show (Fig. 8) that the composition and structure of the $\mathrm{C}-\mathrm{S}-\mathrm{H}$ are very similar in all mixes, in agreement with the observations by SEM-EDX. The mean chain length is around 3.8 and the $\mathrm{Al} / \mathrm{Si}$ atomic ratio around 0.08 (Table 2) and thus slightly lower than the $\mathrm{Al} / \mathrm{Si}$ atomic ratio of 0.12 observed by SEMEDX. The difference between $\mathrm{Al} / \mathrm{Si}$ ratios determined by ${ }^{29} \mathrm{Si}$ NMR and SEM-EDX is usually observed and already been discussed in different papers (see for examples [55-57]). The additives CSA and ACA have little or no impact on the composition of the C-S-H. Although, we have numerous sources of errors in the determination of the degree of hydration (DOH) using XRD-Rietveld (Eq. (4)), we obtain a good agreement between the DOH calculated from NMR and XRD data (Table 2). NMR data also confirm that the hydration of the silicate phases (alite and belite) in the OPC_ACA is lower compared to OPC and OPC_CSA. The spectrum of the hydrated OPC_ACA after $1.5 \mathrm{~h}$ (Fig. 8) indicates that neither $\mathrm{C}-\mathrm{S}-\mathrm{H}$ nor strätlingite is detected (the ${ }^{29} \mathrm{Si}$ NMR spectrum of synthetic strätlingite (not shown) displays a single peak at $86.5 \mathrm{ppm}$ assigned to $\mathrm{Q}_{3}(3 \mathrm{Al})$ or to $\mathrm{Q}_{2}$ silicate species within ring structures [58,59]).

The ${ }^{27} \mathrm{Al}$ NMR spectra of the raw materials, presented in Fig. 9, are in the $\mathrm{Al}(\mathrm{IV})$ range. The spectrum of the OPC reveals the presence of 


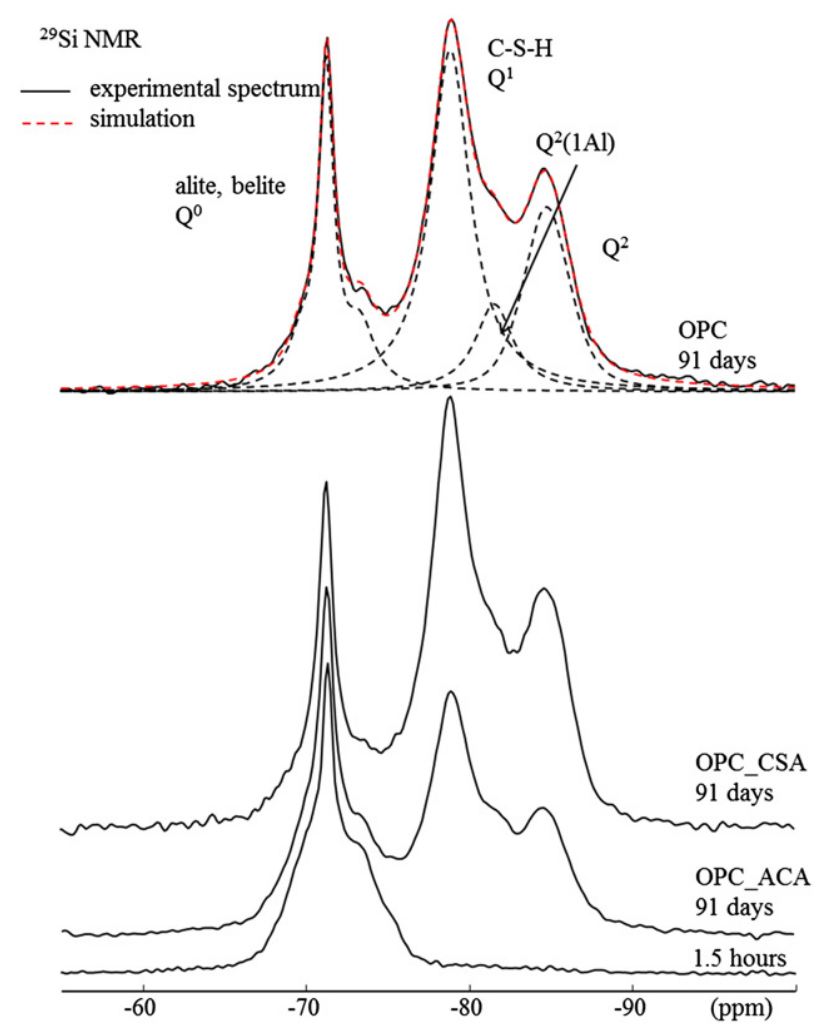

Fig. 8. ${ }^{29}$ Si MAS NMR spectra $\left(9.4 \mathrm{~T}, v_{\mathrm{R}}=4.5 \mathrm{kHz}\right)$ of OPC, OPC_CSA hydrated at 91 days and OPC_ACA pastes hydrated at $1.5 \mathrm{~h}$ and 91 days. The dotted line in red is the simulation of the experimental spectrum OPC.

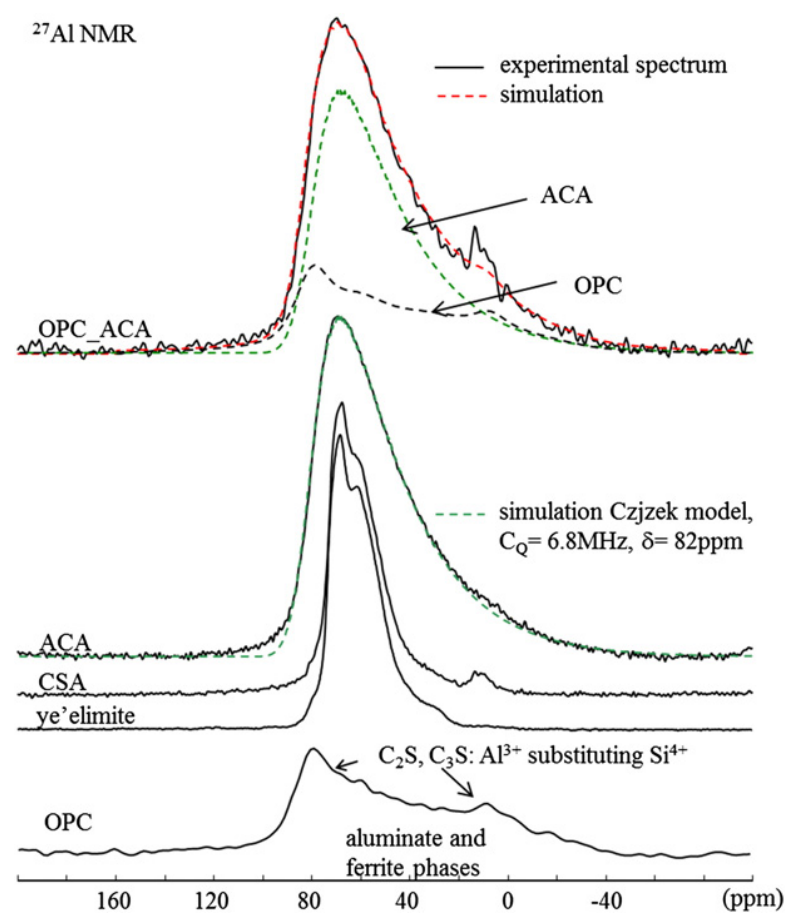

Fig. 9. ${ }^{27} \mathrm{Al}$ MAS NMR spectra $\left(9.4 \mathrm{~T}, \nu_{\mathrm{R}}=20 \mathrm{kHz}\right)$ of anhydrous materials OPC, CSA ACA and the anhydrous blend OPC_ACA. The NMR spectrum of synthetic ye'elimite is presented for comparison with CSA spectrum. The green dotted line represents the simulation of the experimental spectrum ACA using the Czjzek model.
Al substituting $\mathrm{Si}$ in alite and belite and $\mathrm{C}_{3} \mathrm{~A}[60,61]$. Skibsted et al. [62] show that $\mathrm{Al}$ present in the $\mathrm{C}_{4} \mathrm{AF}$ contributes little or no signal to the observed ${ }^{27} \mathrm{Al}$ MAS NMR spectrum because of ${ }^{27} \mathrm{Al}$ nucleus$\mathrm{Fe}^{3+}$ unpaired electron dipolar couplings. The NMR spectrum of the CSA is nearly identical to the spectrum of a synthesized ye'elimite and close to the spectra reported in literature [63,64]. It consists of a single sharp peak with two shoulders to the high field side. At least two types of $\mathrm{AlO}_{4}$ groups are present which is consistent with the description of the structure [63]. The ${ }^{27} \mathrm{Al}$ NMR spectrum of the ACA presents a line associated with $\mathrm{Al}$ in fourfold position. The tailing of the lineshape towards high field is often observed in disordered solids [65]. The line can be fitted using a single component $(\delta=82 \mathrm{ppm}$, $\mathrm{C}_{\mathrm{Q}}=6.8 \mathrm{MHz}$ ) with the Czjzek model. The signal in the spectra of the anhydrous mix OPC_ACA is dominated by the ACA component although around half of the signal should theoretically come from ACA and P (in P_ACA, $\mathrm{Al}_{2} \mathrm{O}_{3}$ originates from OPC and ACA at respectively 47.9 and $52.1 \mathrm{wt} . \%)$. However, the presence of iron in OPC impedes the detection of the entire $\mathrm{Al}$ in this component and the quantification.

The NMR signal of the hydrated pastes in the $\mathrm{Al}(\mathrm{IV})$ range (30-120 ppm) is presented in Fig. 10. The signals of the OPC and OPC_CSA are similar and relatively weak after 1 day. They can be assigned to Al substituting Si both in alite, belite and C-S-H [20]. The strong overlap does not permit to state if the ye'elimite peak around $70 \mathrm{ppm}$ is still present after one day. Although the quantification of ACA from the ${ }^{27} \mathrm{Al}$ NMR experiments is not possible due to a strong overlap with $\mathrm{Al}$ in alite/belite and $\mathrm{C}-\mathrm{S}-\mathrm{H}$, the signal of ACA decreases strongly between 1.5 and $18 \mathrm{~h}$ indicating a consumption of the amorphous part. This strong decrease corresponds well to the strong heat release observed in the OPC_ACA (Fig. 1a). At 91 days, some ACA seems to be still present as observed in SEM-BSE images. However, as we have less C-S-H and more alite/belite, it is difficult to draw a conclusion due to the strong overlap of the different peaks.

In the aluminum sixfold range (Fig. 11), we observe two main peaks that arise from ettringite (around $13 \mathrm{ppm}$ ) and the AFm phase (around $9 \mathrm{ppm}$ ). An example of the decomposition of the spectra is shown in Fig. 12. The small shoulder at around 3.5 ppm may be explained by an amorphous aluminate phase that precipitates at the surface of a $\mathrm{C}-\mathrm{S}-\mathrm{H}$

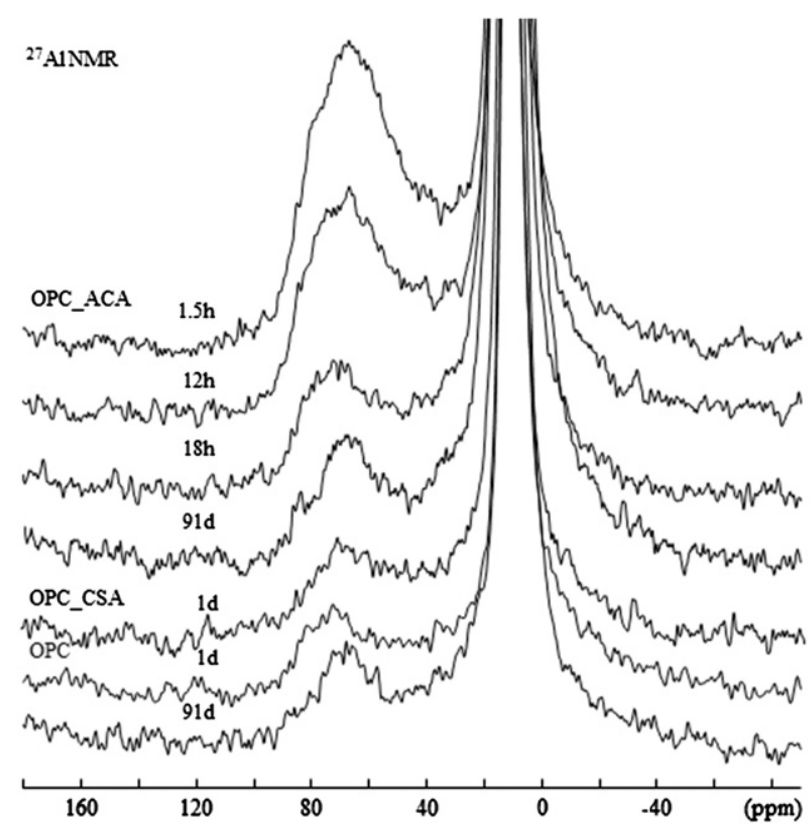

Fig. 10. ${ }^{27} \mathrm{Al}$ MAS NMR spectra $\left(9.4 \mathrm{~T}, v_{\mathrm{R}}=20 \mathrm{kHz}\right)$ of hydrated pastes OPC, OPC_CSA OPC_ACA in the Al(IV) fourfold frequency range. 


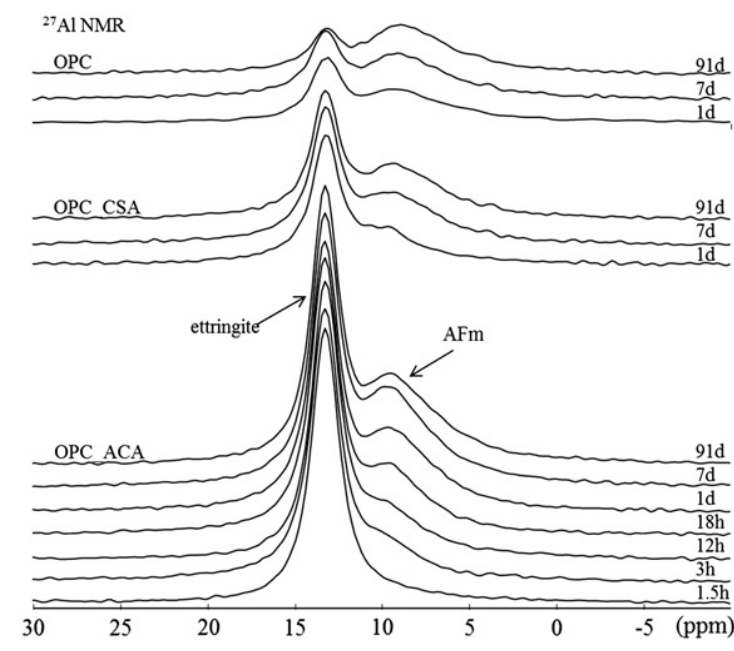

Fig. 11. ${ }^{27} \mathrm{Al}$ MAS NMR spectra $\left(9.4 \mathrm{~T}, v_{\mathrm{R}}=20 \mathrm{kHz}\right)$ of hydrated pastes OPC, OPC_CSA, OPC_ACA in the $\mathrm{Al}(\mathrm{VI})$ sixfold frequency range.

or precipitates as a separate phase (this hypothesis is well supported both by NMR [66] and TEM data [67]). The relative AFm to ettringite weight ratio together with the amount of ettringite from XRD-Rietveld analysis is used to calculate the amount of AFm phases. Note that NMR does not allow distinguishing the different AFm phases.

In the OPC and OPC_CSA, AFm phases appear after $18 \mathrm{~h}$ and longer (see Figs. 5 and 11). In the OPC_ACA, AFm appears already between 1.5 and $3 \mathrm{~h}$ (see Figs. 5 and 11) and the amount increases until seven days as shown in Fig. 3f. The amount of AFm at seven days and after is similar in all systems. No indication of $\mathrm{AH}_{3}$ and strätlingite is observed in any of the systems (peaks around $8 \mathrm{ppm}$ at $9.4 \mathrm{~T}$ for the $\mathrm{AH}_{3}$ [68]; peaks at 60.7 and $9.8 \mathrm{ppm}$ at $9.4 \mathrm{~T}$ for the strätlingite $[58,59])$.

\subsection{Pore solutions}

\subsubsection{Measured concentrations}

During the first $6 \mathrm{~h}$, the composition of pore solution in OPC and OPC_CSA is dominated by K, sulfate, hydroxide, Na and Ca (Fig. 13a and $\mathrm{b}$, Table 3 ). The high concentrations of $\mathrm{K}, \mathrm{Na}$ and sulfate observed

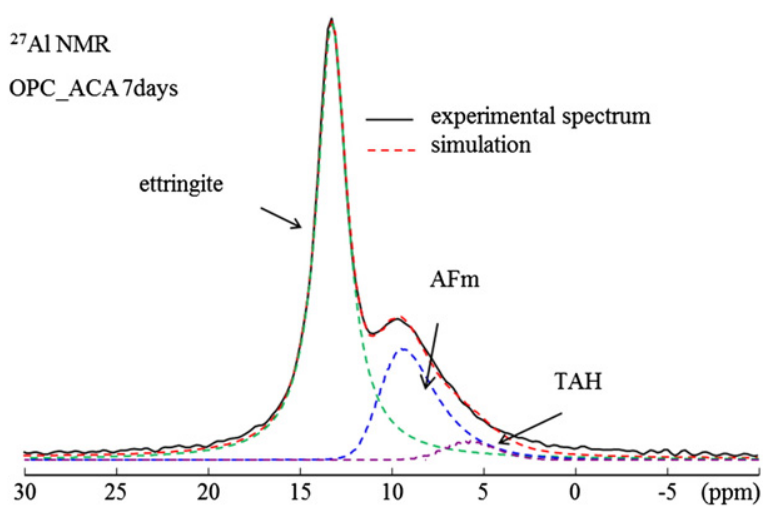

Fig. 12. ${ }^{27} \mathrm{Al}$ MAS NMR spectra $\left(9.4 \mathrm{~T}, v_{\mathrm{R}}=20 \mathrm{kHz}\right)$ of 7 days hydrated paste OPC-ACA in the $\mathrm{Al}(\mathrm{VI})$ sixfold range. A simulation is presented where the dotted line in red is the simulation of the experimental spectrum and the dotted lines the fitted model of ettringite (Lorentz model, $\delta=13.3 \mathrm{ppm}$ ), AFm (Czjzek model, $\delta=10.0 \mathrm{ppm}, \mathrm{C}_{\mathrm{Q}}=1.3 \mathrm{MHz}$ ) and the third aluminate hydrate (TAH) [66] (Czjzek model, $\delta=6.5 \mathrm{ppm}, \mathrm{C}_{\mathrm{Q}}=3.3 \mathrm{MHz}$ ).
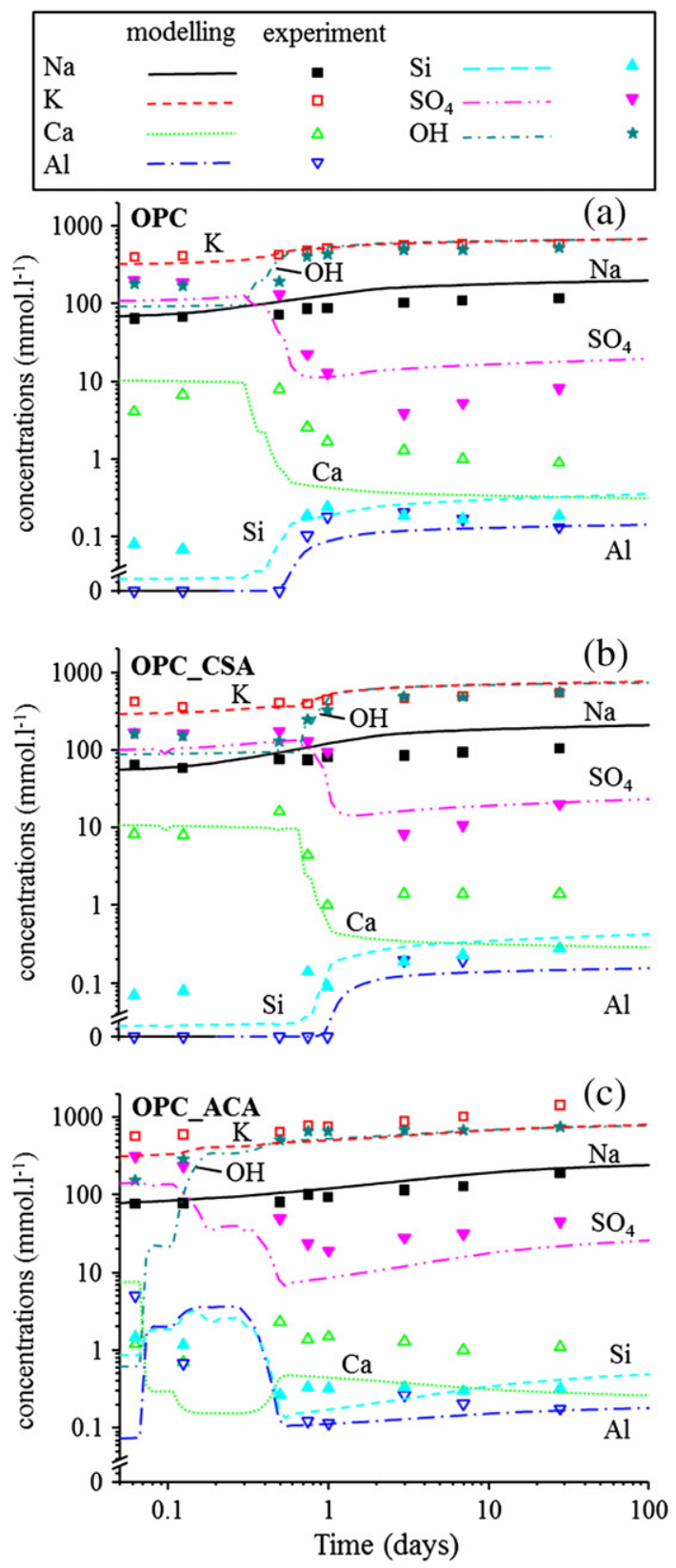

Fig. 13. Modeled concentrations in the liquid phase (lines) compared to the experimentally determined concentrations (symbols) of hydrated pastes OPC (a), OPC_CSA (b) and OPC_ACA (c) as a function of time.

after only a few minutes are due to the fast dissolution of alkalisulfate phases. The observed slow increase of alkali concentrations is (i) due to the decrease of pore solution - as the water present is consumed by the different hydration products - and (ii) due to the release of alkalis trapped in the slowly-hydrating clinker minerals. A part of sodium and potassium ultimately ends up in the solution, while the remaining portion is adsorbed mainly on $\mathrm{C}-\mathrm{S}-\mathrm{H}$.

The concentrations of $\mathrm{Ca}$, sulfate and hydroxide remain more or less constant during the first hours as their concentrations are limited by the presence of gypsum $\mathrm{CaSO}_{4} \cdot 2 \mathrm{H}_{2} \mathrm{O}$ or anhydrite and portlandite $\mathrm{Ca}(\mathrm{OH})_{2}$. The concentrations of $\mathrm{Al}$ and $\mathrm{Si}$ in the pore solution are always very low. Larger changes in the composition of the pore solution of the OPC and OPC_CSA are observed between 6 and $24 \mathrm{~h}$ : Ca and sulfate concentrations decrease drastically, while the concentrations of hydroxide, $\mathrm{Si}$, and $\mathrm{Al}$ all increase at the same time. This decrease in calcium and sulfate concentrations coincides roughly with the 
Table 3

Measured total concentration in the pore solutions gained from cement (OPC) and binders (OPC_CSA, OPC_ACA).

\begin{tabular}{|c|c|c|c|c|c|c|c|c|}
\hline $\begin{array}{l}\text { Time } \\
\text { (days) }\end{array}$ & $\begin{array}{l}\mathrm{Na} \\
\left(\mathrm{mmol} . \mathrm{I}^{-1}\right)\end{array}$ & K & $\mathrm{Ca}$ & $\mathrm{Al}$ & $\mathrm{Si}$ & S & $\mathrm{OH}^{-\mathrm{a}}$ & $\mathrm{pH}$ \\
\hline \multicolumn{9}{|l|}{$O P C$} \\
\hline 0.06 & 65 & 404 & 4.1 & $<0.1$ & 0.08 & 203 & 56 & 13.2 \\
\hline 0.125 & 68 & 418 & 6.8 & $<0.1$ & 0.07 & 191.9 & 97 & 13.1 \\
\hline 0.5 & 73 & 423 & 8 & $<0.1$ & $<0.1$ & 134.1 & 216 & 13.3 \\
\hline 0.75 & 86 & 494 & 2.6 & 0.105 & 0.19 & 22.7 & 487 & 13.5 \\
\hline 1 & 88 & 508 & 1.7 & 0.181 & 0.24 & 12.8 & 518 & 13.5 \\
\hline 3 & 104 & 561 & 1.3 & 0.205 & 0.19 & 3.9 & 593 & 13.6 \\
\hline 7 & 111 & 592 & 1 & 0.17 & 0.17 & 5.3 & 622 & 13.6 \\
\hline 28 & 117 & 598 & 0.9 & 0.133 & 0.19 & 8.2 & 626 & 13.6 \\
\hline \multicolumn{9}{|c|}{ OPC_CSA } \\
\hline 0.06 & 65 & 419 & 8.3 & $<0.1$ & 0.07 & 169.1 & 140 & 13.1 \\
\hline 0.125 & 58 & 352 & 8 & $<0.1$ & 0.08 & 161.5 & 86 & 13.1 \\
\hline 0.5 & 75 & 403 & 16.1 & $<0.1$ & $<0.1$ & 175.5 & 138 & 13.1 \\
\hline 0.75 & 74 & 395 & 4.4 & $<0.1$ & 0.14 & 129.4 & 197 & 13.3 \\
\hline 1 & 80 & 438 & 1 & $<0.1$ & 0.09 & 95 & 299 & 13.4 \\
\hline 3 & 84 & 455 & 1.4 & 0.197 & 0.19 & 8.3 & 479 & 13.6 \\
\hline 7 & 93 & 486 & 1.4 & 0.197 & 0.23 & 10.7 & 509 & 13.6 \\
\hline 28 & 104 & 542 & 1.4 & $<0.1$ & 0.28 & 20.1 & 548 & 13.6 \\
\hline \multicolumn{9}{|c|}{$O P C \_A C A$} \\
\hline 0.06 & 76 & 571 & 1.2 & 5.084 & 1.49 & 313.9 & 2 & 13.1 \\
\hline 0.125 & 78 & 597 & 0.7 & 0.674 & 1.18 & 233.8 & 174 & 13.4 \\
\hline 0.5 & 81 & 652 & 2.3 & $<0.1$ & 0.27 & 49.7 & 562 & 13.6 \\
\hline 0.75 & 100 & 774 & 1.4 & 0.123 & 0.33 & 23.7 & 727 & 13.7 \\
\hline 1 & 94 & 754 & 1.5 & 0.116 & 0.32 & 19.2 & 715 & 13.7 \\
\hline 3 & 115 & 882 & 1.3 & 0.267 & 0.33 & 28.2 & 818 & 13.7 \\
\hline 7 & 127 & 1027 & 1 & 0.204 & 0.3 & 32 & 931 & 13.7 \\
\hline 28 & 190 & 1415 & 1.1 & 0.178 & 0.32 & 44.7 & 1231 & 13.8 \\
\hline
\end{tabular}

The values of $\mathrm{OH}^{-}$refer to the free concentrations. The measured concentrations of Fe are below the detection limit of $0.001 \mathrm{mM}$.

a The free concentrations of $\mathrm{OH}^{-}$are calculated from GEMS.

disappearance of anhydrite and gypsum from the XRD patterns. Then, the pore solution equilibrates with $\mathrm{C}-\mathrm{S}-\mathrm{H}$, portlandite, ettringite and AFm phases. The observed trends in $\mathrm{K}, \mathrm{Na}$, Ca, sulfate, $\mathrm{Si}, \mathrm{Al}$ and hydroxide concentration are consistent with the observations reported for other Portland cements [30,69-72].

In the OPC_ACA system (Fig. 13c, Table 3) and in comparison with the OPC, the Ca concentration is lower during the first hours (which is consistent with the absence of portlandite in the OPC_ACA at early hydration times) whereas the $\mathrm{Al}$ concentration is much higher. As the $\mathrm{C}_{12} \mathrm{~A}_{7}(\mathrm{C} / \mathrm{A}$ ratio $=1.7)$ dissolves very fast and ettringite $(\mathrm{C} / \mathrm{A}$ ratio $=6$ ) precipitates, the $C a$ is rapidly consumed whereas some of the aluminum remains in the solution. The formation of AFm phases at $3 \mathrm{~h}$ ( 0.12 days) consumes some Al. Also the concentration of $\mathrm{Si}$, during the first hours, is relatively high compared to the concentration observed in $\mathrm{P}$. This is probably related to the low Ca concentration, which suppress $\mathrm{C}-\mathrm{S}-\mathrm{H}$ formation during the first hours and lead to the formation of the hydrated shell around the $\mathrm{C}_{12} \mathrm{~A}_{7}$ grains at early age. We can also note that the concentration of sulfate decreases more rapidly than in the other systems due to the fast formation of ettringite. The observed trends are consistent with the concentrations reported by Hirose et al. [9] on a similar system.

\subsubsection{Effective saturation index}

The calculation of saturation indices from the concentrations measured in the pore solutions offers the possibility to asses independently which solid phases can form from a thermodynamic point of view. The effective saturation indices of the different phases are very similar for the OPC and OPC_CSA system (Fig. 14a and b) and similar to the observation made for other Portland cements. The calculated effective saturation indices confirm the presence of portlandite, ettringite, monocarbonate and $\mathrm{C}-\mathrm{S}-\mathrm{H}$ (not shown), which agrees with the TGA and XRD results.
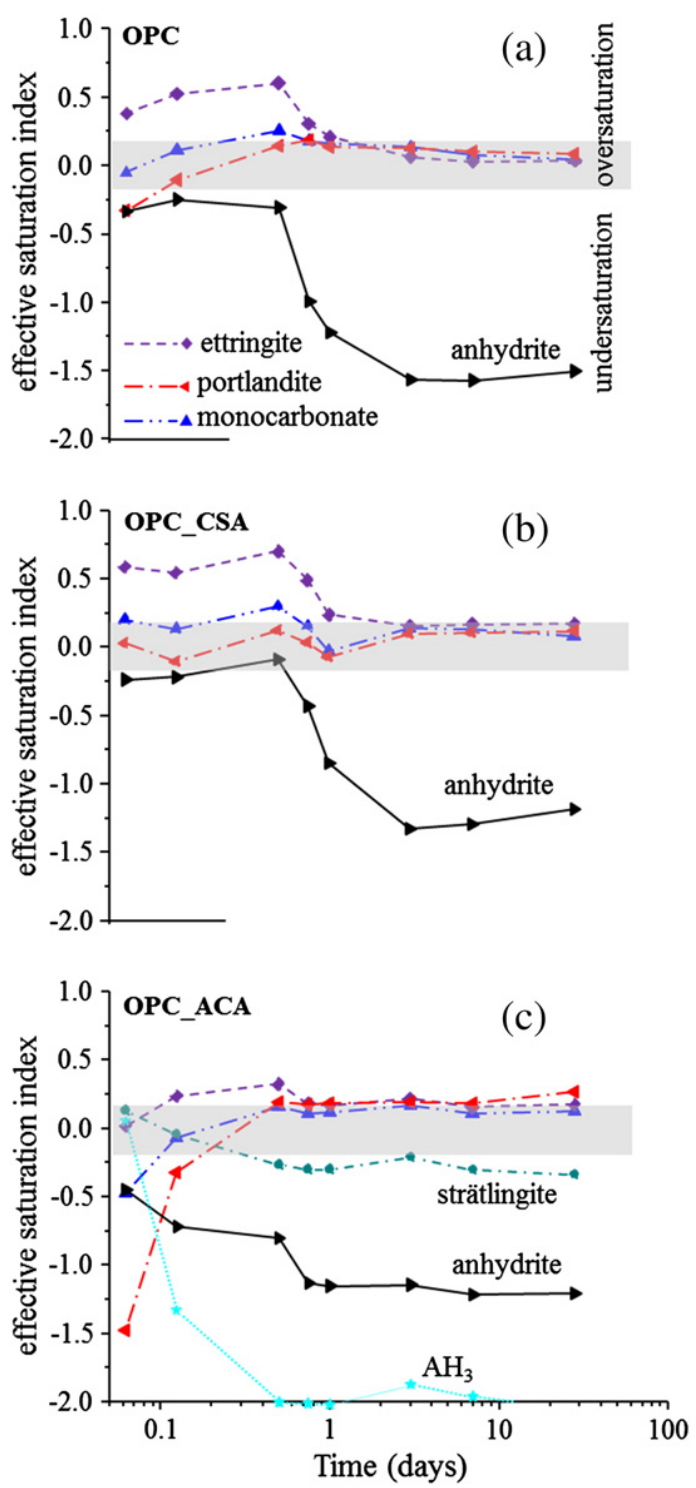

Fig. 14. Effective saturation indices of gypsum, ettringite, portlandite monocarbonate and $\mathrm{AH}_{3}$, strätlingite (in the case of OPC_ACA) of hydrated pastes OPC (a), OPC_CSA (b) and OPC_ACA (c) as a function of time. The shadowed area indicates saturation.

The effective saturation indices also show the dissolution of gypsum and the formation of monocarbonate during the process of hydration. Pore solution is clearly undersaturated with respect to $\mathrm{AH}_{3}$ and strätlingite in these systems (not shown).

The saturation indices calculated in the system OPC_ACA are clearly different from those of other systems at early age (Fig. 14c) while they are similar at later ages. The solution is always oversaturated with respect to ettringite. At early age, the solution is undersaturated with respect to gypsum and portlandite. The undersaturation with respect to anhydrite although anhydrite is observed by XRD (see Fig. 3c) indicates that the remaining anhydrite is dissolving slowly. The undersaturation with respect to portlandite up to $12 \mathrm{~h}$ agrees with the observation of portlandite only after one day (Fig. 3d). The solution is always oversaturated with respect to ettringite. At $1.5 \mathrm{~h}$, the pore solution is saturated with respect to amorphous $\mathrm{AH}_{3}$ and strätlingite, indicating that these solids could precipitate. Strätlingite and $\mathrm{AH}_{3}$ are not detected after $1.5 \mathrm{~h}$, but hydrated shell with a composition closed to strätlingite was observed after 3 h (Fig. 7). 


\subsection{Thermodynamic modeling}

Thermodynamic modeling of the hydration of the OPC, OPC_CSA and OPC_ACA is carried out by combining an empirical model which describes the dissolution of the anhydrous phases as a function of time with the chemical composition of these phases as given in Table 1. The resulting hydrates and the composition of the liquid phase are calculated as a function of time.

\subsubsection{Kinetic input in the thermodynamic model}

The dissolution of the anhydrous phases as function of time is based on the XRD-Rietveld data. The coefficients of the empirical model of Parrot and Killoh are adapted to well represent clinker dissolution $[30,73]$ as shown for alite and aluminate in Fig. 3a and b (belite and ferrite not shown). The ye'elimite in OPC_CSA reacts within one day. The amorphous calcium aluminate phase $\left(C_{12} A_{7}\right)$ in OPC_ACA reacts very fast (Fig. 10) but according to SEM-BSE, some large grains are still present at 28 days. This agree with the observations of Nagawaka et al. [7] in dissolution experiments of amorphous $\mathrm{C}_{12} \mathrm{~A}_{7}$ in water, where a degree of hydration of $24 \mathrm{wt} . \%$ was observed after $15 \mathrm{~s}$ and $62 \mathrm{wt} . \%$ after $30 \mathrm{~min}$. We have assumed that $2 / 3$ of the materials has reacted ( $6.8 \mathrm{wt} . \%$ ) within a few hours and that the reaction stopped afterwards. The empirical functions that have been used to model the degree of reaction of the ye'elimite and $C_{12} A_{7}$ are summarized in Fig. 15.

\subsubsection{Hydrate assemblage}

The predicted hydrates include $\mathrm{C}-\mathrm{S}-\mathrm{H}, \mathrm{CH}$, ettringite and $\mathrm{AFm}$ phases including a small amount of hydrotalcite like phase ( $<2 \mathrm{wt} . \%)$ for all cements as shown in Fig. 16. The presence of the limestone in the OPC leads to the formation of monocarbonate thus indirectly stabilizing ettringite as previously shown [30]. The formation of a small quantity of strätlingite ( $<3 \mathrm{wt} . \%)$ is predicted between 2 and $7 \mathrm{~h}$ in the OPC_ACA and may be related to the hydrated shell observed around $\mathrm{C}_{12} \mathrm{~A}_{7}$ grains after $3 \mathrm{~h}$. The model predicts the complete dissolution of the strätlingite after $7 \mathrm{~h}$ but locally around the $\mathrm{C}_{12} \mathrm{~A}_{7}$, strätlingite may still be present (Fig. $6 \mathrm{~d}$ ) at later ages.

The amount of portlandite, ettringite and "amorphous hydrates" (which includes hydrotalcite besides $\mathrm{C}-\mathrm{S}-\mathrm{H}$ and $\mathrm{AFm}$ ) given by the model (Figs. 3 and 17) is in fair agreement with experimental data. The amount of AFm is overestimated at later age for the OPC_ACA system (see Fig. 3). The amount of aluminum released by $C_{12} A_{7}$ is assumed, in the model, to form $\mathrm{CO}_{3}-\mathrm{AFm}$ at later age. It is difficult to assess if the discrepancies that arise come from errors in the quantification by ${ }^{27} \mathrm{Al} \mathrm{NMR}$, the assumption of $\mathrm{CO}_{3}-\mathrm{AFm}$ in the model or the model, the Al uptake by $\mathrm{C}-\mathrm{S}-\mathrm{H}$, or the modeled degree of

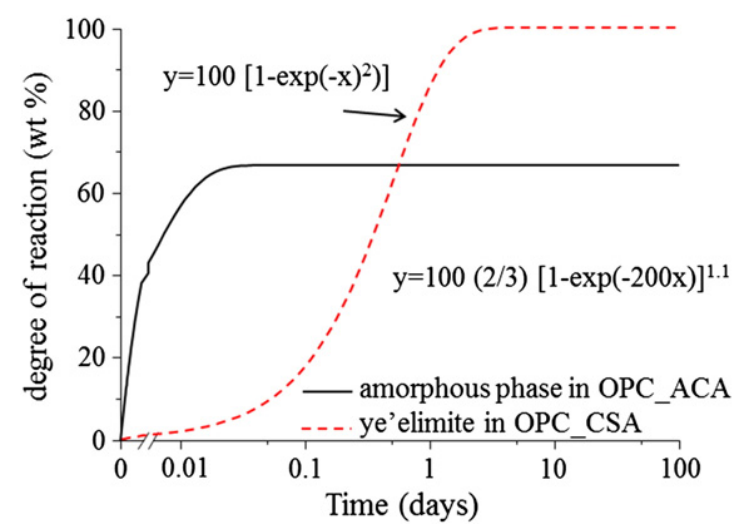

Fig. 15. Degree of reaction of ye'elimite (dotted line) and amorphous phase $C_{12} A_{7}$ in OPC_ACA (plain line) as a function of time used as input in the thermodynamic model.
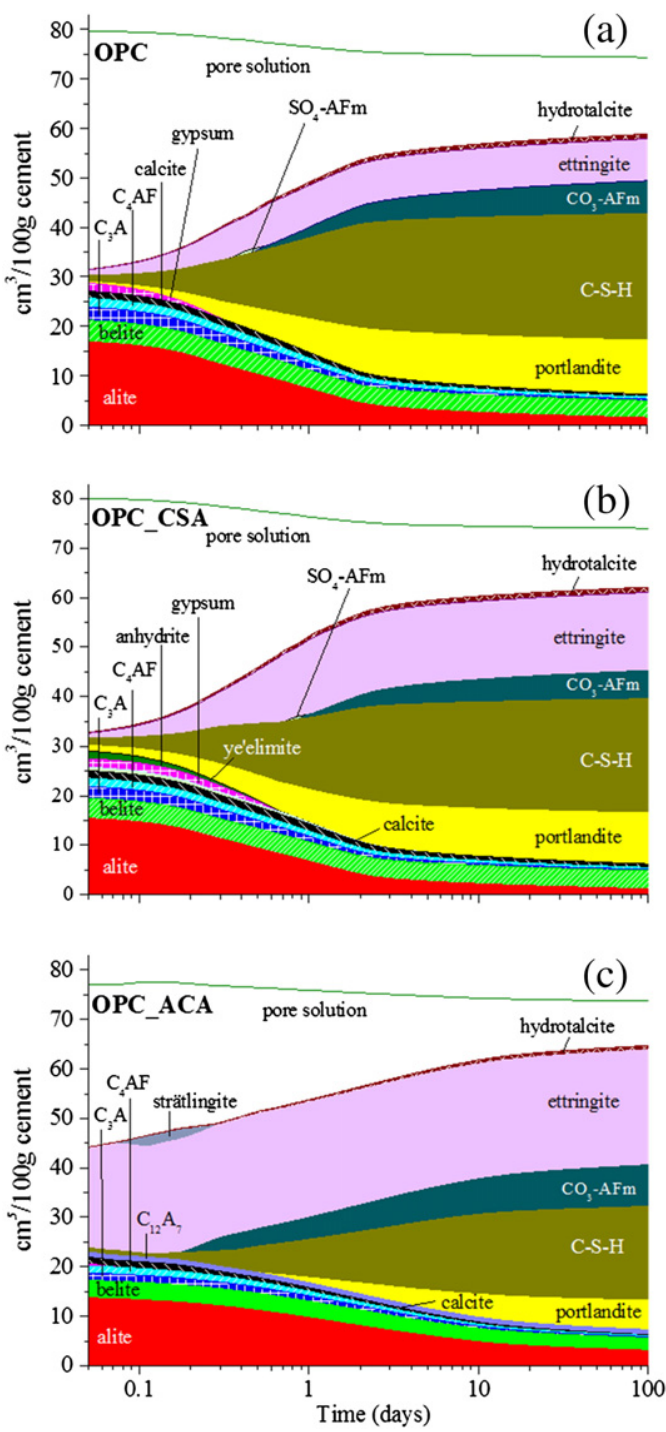

Fig. 16. Modeled changes during the hydration of OPC (a), OPC_CSA (b) and OPC_ACA (c) as a function of time. Volume expressed $\mathrm{as}^{3} / 100 \mathrm{~g}$ unhydrated blended cement.

hydration of $\mathrm{C}_{12} \mathrm{~A}_{7}$. Also the expected concentrations in the pore solution are calculated. The modeled and measured concentrations show consistent trends in all systems (Fig. 13) although hydroxide and sulfate are somewhat overestimated and Ca underestimated.

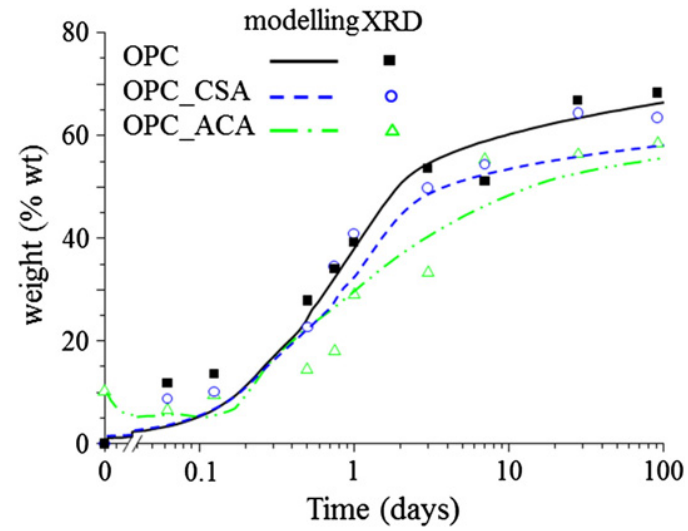

Fig. 17. Amount of X-ray amorphous and AFm hydrated products deduced by XRD/ Rietveld analysis as a function of hydration time. Lines refer to the results of thermodynamic modeling. 


\subsubsection{Chemical shrinkage, porosity and compressive strengths}

Based on the predicted volume of unhydrated blends and hydration products (Fig. 16), the chemical shrinkage $\left(\mathrm{CS}_{\mathrm{GEMS}}\right)$ and the total porosity $\left(\mathrm{P}_{\mathrm{GEMS}}\right)$ can be calculated. The modeled chemical shrinkage is presented in Fig. $2 \mathrm{~b}$. The values are systematically higher than the measured data (Fig. 2a) as the reference point in the model is $x=0$ (Eq. (6)), while the starting point for the measured data is after the first $60 \mathrm{~min}$. If the modeled data for OPC and OPC_CSA would be corrected for the chemical shrinkage calculated for the first $60 \mathrm{~min}$, there would be a reasonable agreement in the trends as well as in the absolute quantities between the modeled and the measured data. The agreement is somewhat less good for the OPC_ACA, as the fast reaction of the amorphous $\mathrm{C}_{12} \mathrm{~A}_{7}$ at early hydration times makes the comparison difficult and very sensitive to the reference time, which is chosen for the start of the chemical shrinkage readings.

The compressive strength is presented in Fig. 18. The modeled porosity corresponds to the total porosity (capillary and gel water), thereby not including cracks or air voids [28]. We obtain a negative relationship between modeled porosity and compressive strength (Fig. 19) except for the OPC_CSA system where a lower compressive strength for the same porosity and a deviance from linearity are observed. As previously reported [10], OPC_CSA generates some voids around CSA grains that give effective expansion to the matrix and may lead to a decrease of the compressive strength. These voids generated by expansion of the CSA are not taken into account in the modeled porosity and might explain the deviance as well as the presence of numerous Hadley grains [74] or the pore structure (not investigated).

\section{Conclusion}

The blending of Portland cements with amorphous $\mathrm{C}_{12} \mathrm{~A}_{7}$-anhydrite (OPC_ACA) or CSA (OPC_CSA) influences not only the hydrate assemblage but also the kinetics of the clinker reaction. The addition of $10 \mathrm{wt} . \%$ CSA to the OPC does not affect the hydration mechanism of alite but retards the $\mathrm{C}_{3} \mathrm{~A}$ reaction due to the presence of sulfates, and increases the amount of ettringite. The higher quantity of ettringite after one day and longer is mirrored in the higher chemical shrinkage in OPC_CSA compared to the OPC. SEM-BSE images show that the pore structure is different from plain Portland cement with numerous Hadley grains in OPC_CSA. The impact of the formation of Hadley grains on the porosity may be important and may explain the deviance in linearity between the modeled porosity and the compressive strength.

In the case of the quick hardening cement OPC_ACA, the amorphous $\mathrm{C}_{12} \mathrm{~A}_{7}$ reacts with the anhydrite present very fast to ettringite. In contrast to pure $\mathrm{C}_{12} \mathrm{~A}_{7}$ systems, no $\mathrm{AH}_{3}$ formation is observed, not even at early reaction times as the aluminum reacts to form AFm phases. After

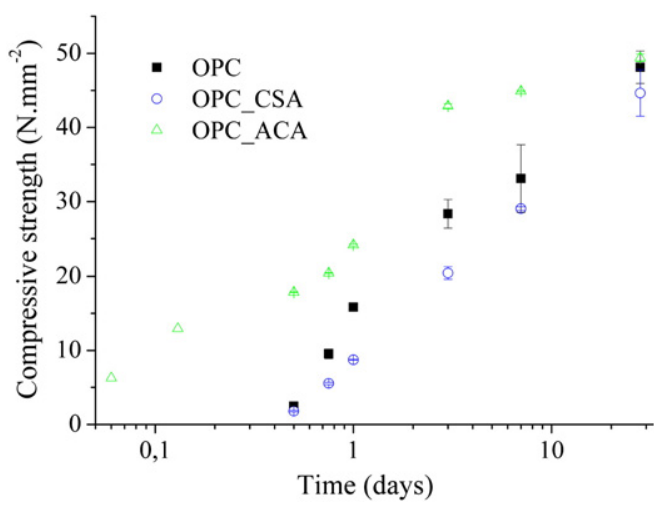

Fig. 18. Compressive strength of hydrated pastes OPC, OPC_CSA and OPC_ACA as a function of time.

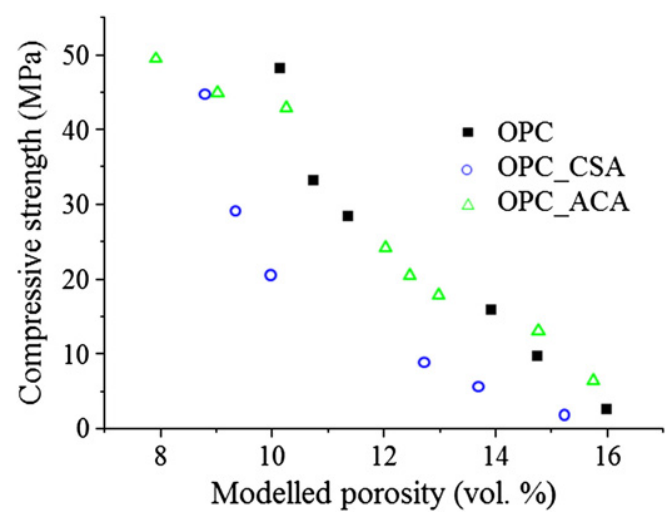

Fig. 19. Relation between compressive strength and modeled porosity.

$3 \mathrm{~h}$, a shell with a composition close to strätlingite occurs around the $\mathrm{C}_{12} \mathrm{~A}_{7}$ grains. The formation of strätlingite and the absence of portlandite at early age are also predicted by thermodynamic modeling. Large grains of $\mathrm{C}_{12} \mathrm{~A}_{7}$ are still visible at 28 days; the formation of hydrated shell around the grains may hinder the further hydration of $\mathrm{C}_{12} \mathrm{~A}_{7}$ at later ages. The release of aluminate ions strongly retards the hydration of alite but the $\mathrm{C}-\mathrm{S}-\mathrm{H}$ has a similar composition as in OPC with no additional $\mathrm{Al}$ to $\mathrm{Si}$ substitution. As in OPC_CSA, the $\mathrm{C}_{3} \mathrm{~A}$ hydration is controlled by the availability of sulfates. The strong increase of the chemical shrinkage at early age is explained by the fast formation of ettringite.

The coupling of thermodynamic modeling with the kinetic equations that describe the dissolution of the OPC, CSA and $\mathrm{C}_{12} \mathrm{~A}_{7}$ predicts the amount of hydrates and pore solution compositions as a function of time adequately. This validates the model for Portland cement with mineral additions based on $\mathrm{CaO}, \mathrm{SO}_{3}$ and $\mathrm{Al}_{2} \mathrm{O}_{3}$ although further studies are needed to characterize the AFm phases and the degree of hydration of $\mathrm{C}_{12} \mathrm{~A}_{7}$.

\section{Acknowledgments}

The authors would like to acknowledge D. Rentsch (Empa, Lab. for Functional Polymers) for his support during the NMR experiments, B. Ingold, L. Brunetti, and A. Steffen for their experimental support in the laboratory, M. Ben Haha and F. Deschner for the SEM analysis, T. Matschei (Univ. Aberdeen) for providing us with synthetic strätlingite and R. Yoshino, T. Mori (Denka) for their useful comments.

\section{References}

[1] I. Odler, Special inorganic cements, in: A. Bentur, S. Mindness (Eds.), Modern Concrete Technology Series 8, E\&FN Spon, 2000.

[2] E. Sakai, Y. Nikaido, T. Itoh, M. Daimon, Ettringite formation and microstructure of rapid hardening cement, Cem. Concr. Res. 34 (2004) 1669-1673.

[3] S. Nagataki, H. Gomi, Expansive admixtures (mainly ettringite), Cem. Concr. Compos. 20 (1998) 163-170.

[4] H.F.W. Taylor, Cement Chemistry, 2nd edition Thomas Teldford, 1997.

[5] N. Kondo, Y. Nikaido, S. Nakaya, M. Handa, T. Ando, E. Sakai, M. Daimon, Relationship between ettringite formation and the development of strength for rapid hardening cement, in: H. Justnes (Ed.), Proceedings of the 10th International Congress on the Chemistry of Cement (ICCC), Paper 2ii017, (Gothenburg, Sweden, 1997.

[6] C. Hesse, F. Goetz-Neunhoeffer, J. Neubauer, A new approach in quantitative in-situ XRD of cement pastes: correlation of heat flow curves with early hydration reactions, Cem. Concr. Res. 41 (2011) 123-128.

[7] K. Nakagawa, I. Terashima, K. Asaga, M. Daimon, A study of hydration of amorphous calcium aluminate by selective dissolution analysis, Cem. Concr. Res. 20 (1990) 655-661.

[8] K. Nakagawa, I. Terashima, K. Asaga, M. Daimon, Influence of $\mathrm{Ca}(\mathrm{OH})_{2}$ and $\mathrm{CaSO}_{4} \cdot 2 \mathrm{H}_{2} \mathrm{O}$ on hydration reaction of amorphous calcium aluminate, $\mathrm{Cem}$. Concr. Res. 20 (1990) 824-832.

[9] S. Hirose, T. Higaki, K. Asaga, M. Daimon, Study on hydration and the properties of hardening accelerators based on calcium-aluminate glass, in: H. Justnes (Ed.), Proceedings of the 10th International Congress on the Chemistry of Cement (ICCC), Paper 3iii022, Gothenburg, Sweden, 1997. 
[10] K. Nakagawa, Y. Watanabe, I. Mino, T. Kitsuta, Adoption of Electrofused Calcium Sulphoaluminate Clinker for Ultra-high Strength Concrete, Proceedings of the 6th International Congress on the Chemistry of Cement (ICCC), Supplementary Paper, Section 3, URSS, Moscow, 1974.

[11] B. Lothenbach, F. Winnefeld, Thermodynamic modelling of the hydration of Portland cement, Cem. Concr. Res. 36 (2006) 209-226.

[12] L. Wadsö, Applications of an eight-channel isothermal conduction calorimeter for cement hydration studies, Cem. Int. 3 (2005) 94-101.

[13] G. Le Saout, V. Kocaba, K. Scrivener, Application to the Rietveld method to the analysis of anhydrous cement, Cem. Concr. Res. 41 (2011) 133-148.

[14] L. Pelletier- Chaignat, F. Winnefeld, B. Lothenbach, G. Le Saout, C.J. Müller, C. Famy, Influence of the calcium sulphate source on the hydration mechanism of Portland cement-calcium sulphoaluminate clinker-calcium sulphate binders, Cem. Concr. Compos. 33 (2011) 551-561.

[15] R.L. Snyder, D.L. Bish, Quantitative analysis, in: D.L. Bish, J.E. Post (Eds.), Modern Powder Diffraction, Reviews in Mineralogy, 20, Mineralogical Society of America, 1989, pp. 101-144

[16] B.H. O'Connor, M.D. Raven, Application of the Rietveld refinement procedure in assaying powdered mixtures, Powder Diffract. 3 (1988) 2-6.

[17] D. Jansen, F. Goetz-Neunhoeffer, C. Stabler, J. Neubauer, A remastered external standard method applied to the quantification of early OPC hydration, Cem. Concr. Res. 41 (2011) 602-608.

[18] D. Massiot, F. Fayon, M. Capron, I. King, S. Le Calvé, B. Alonso, J.-P. Durand, B. Bujoli, Z. Gan, G. Hoatson, Modelling one- and two-dimensional solid-state NMR spectra, Magn. Reson. Chem 40 (2002) 70-76.

[19] I.G. Richardson, A.R. Brough, G.W. Groves, C.M. Dobson, The characterization of hardened alkali-activated blast-furnace slag pastes and the nature of the calcium silicate hydrate (C-S-H) phase, Cem. Concr. Res. 24 (1994) 813-829.

[20] J. Skibsted, H.J. Jakobsen, in: P. Colombet, A.-R. Grimmer, Characterization of the calcium silicate and aluminate phases in anhydrous and hydrated Portland cements, In: P. Colombet, A.-R. Grimmer, H. Zanni, P. Soozzani (Eds.), Nuclear Magnetic Resonance Spectroscopy of Cement-Based Materials, Springer, Berlin, 1998, pp. 3-45.

[21] G. Czjzek, J. Fink, F. Gotz, H. Schmidt, J.M.D. Coey, J.-P. Rebouillat, A. Liénard, Atomic coordination and the distribution of electric field gradients in amorphous solids, Phys. Rev. B 23 (1981) 2513-2530.

[22] J.-B. D'Espinose de Lacaillerie, C. Fretigny, D. Massiot, MAS NMR spectra of quadrupolar nuclei in disordered solids: the Czjzek model, J. Magn. Reson. 192 (2008) 244-251.

[23] ASTM Standard C 1608-07, Standard Test Method for Chemical Shrinkage of Hydraulic Cement Paste, ASTM International, West Conshohocken, USA, 2007.

[24] D. Kulik, GEMS-PSI 3. Available for version 3 at http://gems.web.psi.ch/2011(PSIVilligen, Switzerland).

[25] D. Kulik, U. Berner, E. Curti, Modelling geochemical equilibrium partitioning with the GEMS-PSI Code, in: B. Smith, B. Gschwend (Eds.), Paul Scherrer Institut Scientific Report 2003, Nuclear Energy and Safety, vol. IV, 2004, pp. 109-122.

[26] W. Hummel, U. Berner, E. Curti, FJ. Pearson, T. Thoenen, Nagra/PSI Chemical Thermodynamic Data Base 01/01, Universal Publishers, Parkland, Florida USA, 2002.

[27] T. Matschei, B. Lothenbach, F.P. Glasser, Thermodynamic properties of Portland cement hydrates in the system $\mathrm{CaO}-\mathrm{Al}_{2} \mathrm{O}_{3}-\mathrm{SiO}_{2}-\mathrm{CaSO}_{4}-\mathrm{CaCO}_{3}-\mathrm{H}_{2} \mathrm{O}$, Cem. Concr. Res. 37 (2007) 1379-1410.

[28] B. Lothenbach, T. Matschei, G. Möschner, F.P. Glasser, Thermodynamic modelling of the effect of temperature on the hydration and porosity of Portland cement, Cem. Concr. Res. 38 (2008) 1-18.

[29] T. Schmidt, B. Lothenbach, M. Romer, K.L. Scrivener, D. Rentsch, R. Figi, A thermodynamic and experimental study of the conditions of thaumasite formation, Cem. Concr. Res. 38 (2008) 337-349.

[30] B. Lothenbach, G. Le Saout, E. Gallucci, K. Scrivener, Influence of limestone on the hydration of Portland cements, Cem. Concr. Res. 38 (2008) 848-860.

[31] B. Lothenbach, G. Le Saout, M. Ben Haha, R. Figi, E. Wieland, Hydration of low-alkali CEM III/B-SiO 2 cement (LAC), Cem. Concr. Res. 42 (2012) 410-423.

[32] F. Winnefeld, B. Lothenbach, in: Hydration of Calcium Sulfoaluminate Cements Experimental Findings and Thermodynamic Modeling, 40, 2010, pp. 1239-1247.

[33] L. Pelletier, F. Winnefeld, B. Lothenbach, The ternary system Portland cement-calcium sulphoaluminate clinker-anhydrite: hydration mechanism and mortar properties, Cem. Concr. Compos. 32 (2010) 497-507.

[34] D.A. Kulik, M. Kersten, Aqueous solubility diagrams for cementitious waste stabilization systems: 4 . A carbonation model for $\mathrm{Zn}$-doped calcium-silicate hydrate by Gibbs energy minimization, Enviro. Sci. Technol. 36 (2002) 2926-2931.

[35] D.A. Kulik, M. Kersten, Aqueous solubility diagrams for cementitious waste stabilization systems: II, emd-member stoichiometries of ideal calcium silicate hydrate solid solutions, J. Am. Ceram. Soc. 84 (2001) 3017-3026.

[36] S.-Y. Hong, F.P. Glasser, Alkali binding in cement pastes, part I. The C-S-H phase, Cem. Concr. Res. 29 (1999) 1893-1903.

[37] D. Jansen, F. Goetz-Neunhoeffer, B. Lothenbach, J. Neubauer, The early hydration of ordinary Portland cement (OPC): an approach comparing measured heat flow with calculated heat flow from QXRD, Cem. Concr. 42 (2012) 134-138.

[38] J.W. Bullard, H.M. Jennings, R.A. Livingston, A. Nonat, G.W. Scherer, J.S. Schweitzer K.L. Scrivener, J.J. Thomas, Mechanism of cement hydration, Cem. Concr. 41 (2011) 1208-1223.

[39] G. Le Saout, M. Ben Haha, Effect of filler on early hydration, in: A. Palomo (Ed.), Proceedings of the 13th International Congress on the Chemistry of Cement (ICCC), Madrid, Spain, 2011.
[40] W. Nocuń-Wczelik, A. Stok, Z. Konik, Heat evolution in hydrating expansive cement systems, J. Therm. Anal. Calorim. 101 (2010) 527-532.

[41] H. Minard, S. Garrault, L. Regnaud, A. Nonat, Mechanisms and parameters controlling the tricalcium aluminate reactivity in the presence of gypsum, Cem. Concr. Res. 37 (2007) 1418-1426.

[42] D. Damidot, A. Rettel, Effect of gypsum on $C A$ and $C_{12} A_{7}$ hydration at room temperature, in: G. Grieve, G. Owens (Eds.), Proceedings of the 11th International Congress on the Chemistry of Cement (ICCC), Durban, South Africa, 2003 pp. $1855-1865$.

[43] F. Goetz-Neunhoeffer The function of Li carbonate and tartaric acid in the hydration of mixtures of calcium aluminate cement $(C A C)$ with calcium sulfate hemihydrate $\left(C \bar{S} H_{0.5}\right)$, Cem. Int. 5 (2007) 90-101.

[44] S. Garrault, A. Nonat, Y. Sallier, L. Nicoleau, On the origin of the dormant period of cement hydration, in: A. Palomo (Ed.), Proceedings of the 13th International Congress on the Chemistry of Cement (ICCC), Madrid, Spain, 2011.

[45] D. Damidot, A. Rettel, Study of the interaction between the hydration of CA and of $\mathrm{C}_{3} \mathrm{~S}$ at room temperature, in: G. Grieve, G. Owens (Eds.), Proceedings of the 11th International Congress on the Chemistry of Cement (ICCC), Durban, South Africa, 2003, pp. 1845-1854.

[46] P. Lura, F. Winnefeld, S. Klemm, Simultaneous measurements of heat of hydration and chemical shrinkage on hardening cement pastes, J. Therm. Anal. Calorim. 101 (2010) 925-932.

[47] F. Winnefeld, S. Barlag, Calorimetric and thermogravimetric study on the influence of calcium sulfate on the hydration of ye'elimite, J. Therm. Anal. Calorim. 101 (2010) 949-957.

[48] F. Winnefeld, S. Barlag, Influence of calcium sulfate and calcium hydroxide on the hydration of calcium sulfo-aluminate clinker, ZKG Int. 12 (2009) 42-53.

[49] J.T. Kloprogge, H.D. Ruan, R.L. Frost, Thermal decomposition of bauxite minerals: infrared emission spectroscopy of gibbsite, boehmite and diapore, J. Mater. Sci. 37 (2002) 1121-1129.

[50] D.G. Evans, R.C.T. Slade, Structural aspects of layered double hydroxides, Struct. Bond. 119 (2006) 1-87.

[51] S. Guggenheim, D.C. Bain, F. Bergaya, M.F. Brigatti, V.A. Drits, D.D. Eberl, M.L.L. Formoso, E. Galan, R.J. Merriman, D.R. Peacor, H. Stanjek, T. Watanabe, Report of the association international pour l'étude des argiles (AIPEA) nomenclature committee for 2001: order, disorder and crystallinity in phyllosilicates and the use of the "crystallinity index", Clays Clay Miner. 50 (2002) 406-409.

[52] K.L. Scrivener, Backscattered electron imaging of cementitious microstructures: understanding and quantification, Cem. Concr. Compos. 26 (2004) 935-945.

[53] R. Rinaldi, M. Sacerdoti, E. Passaglia, Strätlingite: crystal structure, chemistry, and a reexamination of its polytype vertumnite, Eur. J. Mineral. 2 (1990) 841-849.

[54] J. Ding, Y. Fu, J.J. Beaudoin, Strätlingite formation in high-alumina cement-zeolite systems, Adv. Cem. Res. 7 (1995) 171-178.

[55] I.G. Richardson, J. Skibsted, L. Black, R.J. Kirkpatrick, Characterisation of cement hydrate phases by TEM, NMR and Raman spectroscopy, Adv. Cem. Res. 22 (2010) 233-248.

[56] M.D. Andersen, H.J. Jakobsen, J. Skibsted, A new aluminum hydrate species in hydrated Portland cements characterized by ${ }^{27} \mathrm{Al}$ and ${ }^{29} \mathrm{Si}$ MAS NMR spectroscopy, Cem. Concr. Res. 36 (2006) 3-17

[57] G. Le Saout, M. Ben Haha, F. Winnefeld, B. Lothenbach, Hydration degree of alkali-activated slags: a ${ }^{29}$ Si NMR study, J. Am. Ceram. Soc. 94 (2011) 4541-4547.

[58] S. Kwan, J. LaRosa, M.W. Grutzeck, ${ }^{29} \mathrm{Si}$ and ${ }^{27} \mathrm{Al}$ MASNMR study of strätlingite, J. Am. Ceram. Soc. 78 (1995) 1921-1926.

[59] W. Gessner, D. Müller, Festkörper-NMR-untersuchungen am gehlenite hydrate $2 \mathrm{CaO} \mathrm{Al} \mathrm{O}_{3} \mathrm{SiO}_{2} 8 \mathrm{H}_{2} \mathrm{O}$, Z. Chem. 29 (1989) 344-345.

[60] J. Skibsted, H.J. Jakobsen, Direct observation of aluminium guest ions in the silicate phases of cement minerals by ${ }^{27} \mathrm{Al}$ MAS NMR spectroscopy, J. Chem. Soc. Faraday Trans. 90 (1994) 2095-2098.

[61] G. Le Saout, E. Lécolier, A. Rivereau, H. Zanni, Chemical structure of cement aged at normal and elevated temperature and pressures. Part I: Class $\mathrm{G}$ oilwell cement, Cem. Concr. Res. 36 (2006) 71-78.

[62] J. Skibsted, H.J. Jakobsen, C. Hall, Quantitative aspects of 27Al MAS NMR of aluminoferrites, Advn. Cem. Bas. Mat. 7 (1998) 57-59.

[63] N.J. Calos, C.H.L. Kennard, A.K. Whittaker, R.L. Davis, Structure of calcium aluminate sulfate $\mathrm{Ca}_{4} \mathrm{Al}_{6} \mathrm{O}_{16} \mathrm{~S}$, J. Solid State Chem. 119 (1995) 1-7.

[64] J.-T. Song, J.-F. Young. Direct synthesis and hydration of calcium aluminosulfate $\left(\mathrm{Ca}_{4} \mathrm{Al}_{6} \mathrm{O}_{16} \mathrm{~S}\right)$, J. Am. Ceram. Soc. 85 (2002) 535-539.

[65] D. Massiot, B. Cote, F. Taulelle, J.-P. Coutures, ${ }^{27}$ Al MAS NMR of crystalline and amorphous materials, in: P. Colombet, A.-R. Grimmer (Eds.), Application of NMR Spectroscopy to Cement Science, Gordon and Breach Science Publishers, 1994, pp. 153-169.

[66] M.D. Andersen, H.J. Jakobsen, J. Skibsted, Incorporation of aluminium in the calcium silicate hydrate $(\mathrm{C}-\mathrm{S}-\mathrm{H})$ of hydrated Portland cements: a high-field ${ }^{27} \mathrm{Al}$ and ${ }^{29} \mathrm{~S}$ NMR investigation, Inorg. Chem. 42 (2003) 2280-2287.

[67] R. Taylor, I.G. Richardson, R.M.D. Brydson, Composition and microstructure of 20- year-old ordinary Portland cement-ground granulated blast-furnace slag blends containing 0 to $100 \%$ slag, Cem. Concr. Res. 26 (2010) 971-983.

[68] A. Vyalikh, K. Zesewitz, U. Scheler, Hydrogen bonds and local symmetry in the crystal structure of gibbsite, Magn. Res. Chem. 48 (2010) 877-881.

[69] D. Rothstein, J.J. Thomas, B.J. Christensen, H.M. Jennings, Solubility behavior of Ca-, S-, Al-, and Si-bearing solid phases in Portland cement pore solutions as a function of hydration time, Cem. Concr. Res. 32 (2002) 1663-1671.

[70] W. Schwarz, Novel cement matrices by accelerated hydration of the ferrite phase in Portland cement via chemical activation: kinetics and cementitious properties, Advn. Cem. Bas. Mat. 2 (1995) 189-200. 
[71] F.W. Locher, W. Richartz, S. Sprung, Erstarren von Zement I: Reaktion und Gefügeentwicklung, Zement-Kalk-Gips 29 (1976) 435-442.

[72] P. Gunkel, Die Zusammensetzung der flüssigen Phase erstarrender und erhärtender Zemente, Beton-Informationen 23 (1983) 3-8.
[73] L.J. Parrott, D. Killoh, Precipitation of cement hydration, Br. Ceram. Proc. 35 (1984) 41-53.

[74] S. Diamond, D. Bonen, Microstructure of hardened cement paste - a new interpretation, J. Am. Ceram. Soc. 76 (1993) 2993-2999. 